\author{
PAULA MUES ORTS
}

ESCUELA NACIONAL DE CONSERVACIÓN, RESTAURACIÓN Y MUSEOGRAFÍA, INAH

\title{
Los siete colores de la Pintura: tratadística y afirmación pública de la dignidad del arte en el siglo XVII novohispano
}

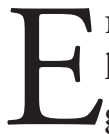

N EL MUNDO HISPÁNiCo la emblemática, y aún de manera más amplia la cultura emblemática, sirvió en diversas ocasiones de herramienta a grupos sociales específicos para transmitir a la sociedad preocupaciones e intereses concretos, incluso para realizar peticiones a los gobernantes. En el caso que aquí se narra los pintores de la ciudad de México fueron quienes, en ocasión de las celebraciones de la mayoría de edad y la toma del gobierno personal de Carlos II en I676, alzaron la voz y desplegaron un especial conjunto de imágenes para llamar la atención del arzobispo virrey fray Payo Enríquez de Ribera y su comitiva. Es, por tanto, un caso de "emblemática aplicada", la cual se caracteriza por usar estrategias discursivas en las que los emblemas se convierten en "instrumentos de propaganda de [...] intereses ideológicos, políticos

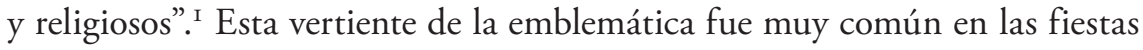
del orbe hispánico, en que el receptor era masivo y múltiple y acudía al regocijo atraído por la riqueza visual y la espectacularidad. "De este modo, entre los dos polos rectores de la composición emblemática, hacer ver/hacer compren-
\end{abstract}

I. Giuseppina Ledda, "Estrategias y procedimientos comunicativos en la emblemática aplicada (fiestas y celebraciones, siglo xviI)", en Rafael Zafra y José Javier Azanza (eds.), Emblemata áurea. La emblemática en el arte y la literatura del Siglo de Oro, Madrid, Akal, 2000 , pp. 25 I-252 y ss. En contraposición a la emblemática aplicada, la autora habla de una emblemática áurea o alta. 
der, en la lectura solitaria predomina el comprender, en la emblemática aplicada, sin duda, el ver", 2 sentido rector de los artífices del pincel.

En el esplendor visual de las fiestas de 1676 entró en juego un ambiente político que debemos comprender para desvelar por qué los pintores hicieron gala de la liberalidad de su actividad en una gran máscara emblemática, "panegírico más glorioso, con muda persuasiva, con retórica callada, distinta en colores, epígrafes, flores, empresas, jeroglíficos, ornamentos, emblemas, motes, con que oró acompañado de la fineza el silencio", en palabras de su cronista, el poeta cortesano Alonso Ramírez de Vargas. ${ }^{3}$

\section{Grandisima nueva: no viene virrey}

El i6 de noviembre de I673 llegó desde Chapultepec a la ciudad de México el nuevo virrey de la Nueva España, Pedro Nuño Colón de Portugal y Castro, duque de Veragua, quien sustituiría a Antonio Sebastián de Toledo Molina y Salazar, marqués de Mancera, que dejaba su cargo tras nueve años de gobierno. El duque de Veragua entró públicamente el 8 de diciembre a la ciudad de México, donde fue recibido por el arzobispo fray Payo Enríquez de Ribera y celebrado con adornos en las calles que incluyeron arco y portada triunfales con sus respectivas loas. La novedad de su gobierno, sin embargo, fue tan efímera como las fiestas que lo acogieron, pues cinco días después, a las cinco de la tarde, se anunció su muerte: había fallecido sin recibir los sacramentos a las cinco de la mañana. $\mathrm{Al}$ anochecer de ese día I3 se abrieron, en el salón del real acuerdo de Palacio, los pliegos de mortaja, en los que se designaba como virrey al maestro y arzobispo fray Payo Enríquez de Ribera. ${ }^{4}$

Su nombramiento contaba con el aval de la regenta Mariana de Austria y la Junta de Gobierno que había formado su difunto esposo Felipe IV en el

2. Ibidem, pp. 252-253.

3. Alonso Ramírez de Vargas describió los festejos en honor a Carlos II en la relación titulada Sencilla narración..., impresa en México por la viuda de Bernardo Calderón en I677. Para este trabajo utilicé la edición del texto del poeta incluida en Dalmacio Rodríguez Hernández, Texto y fiesta en la literatura novohispana (I650-I700), México, Universidad Nacional Autónoma de México-Instituto de Investigaciones Bibliográficas, 1998, p. 233. En adelante la citaré como Ramírez de Vargas.

4. Antonio de Robles, Diario de sucesos notables, Antonio Castro Leal (ed. y pról.), México, Porrúa, I946, t. I, pp. I37-I39. 
lecho de muerte. Mariana, aconsejada siempre por la Junta, gobernaba desde 1665 en nombre de su hijo Carlos José, único varón sobreviviente del matrimonio y por tanto heredero del trono, con tan sólo cuatro ańos.5 Hacia las fechas en que fray Payo Enríquez de Ribera asumió el gobierno virreinal, la reina madre había logrado ganar un poco de control sobre este consejo, acercando a la Junta hombres influyentes de la corte apegados a ella y contrarios al hijo ilegítimo del rey, Juan José de Austria, quien luchaba por ganar adeptos para unirse a su medio hermano y gobernar a su lado. ${ }^{6}$ En I673, Carlos II tenía I2 años y aún debería esperar dos más para poder asumir las riendas de su gobierno personal.

Al tiempo que esta inestable situación se desarrollaba en España, parecía que para la Nueva Espańa se buscaba la estabilidad. Así, casi dos años después de la muerte del duque de Veragua, el I6 de septiembre de I675 Antonio de Robles escribió sorprendido en su diario: "Flota [...] entró nueva de la flota estando en acuerdo a las cuatro y media de la tarde; no viene virrey: grandísima nueva"? ¿Por qué a Robles le parecía un suceso la falta de remplazo del virrey?, ¿por qué la permanencia en el gobierno de fray Payo era una "nueva"? Como agudo observador, Robles sabía que el arzobispo-virrey podría ser remplazado en cualquier momento, pues su gobierno, transitorio al fin, sumaba días pese a la costumbre de no dejar en funciones por tiempo prolongado a los virreyes interinos, más aún en el caso de prelados diocesanos. De hecho, en los siguientes días y meses, el cronista señaló varias veces los rumores acerca de una posible sustitución del poder virreinal. ${ }^{8}$ Aunque en esos momentos no lo sabía nadie, el interinato de fray Payo sería el más largo de todo el periodo virreinal, abarcando desde diciembre de 1673 hasta noviembre de I680. ${ }^{9}$

5. El ambiente de la regencia de Mariana de Austria y sus relaciones con Juan, hijo ilegítimo de Felipe IV, fueron tomados de Henry Kamen, Spain in the Later Seventeenth Century, I665-1700, Londres, Longman, I983, pp. 328-356.

6. Ibidem, pp. 334-339.

7. Robles, op. cit., p. I 82. Las cursivas son mías.

8. El i6 de mayo de i676, Robles apuntó que corría el rumor de que venía como virrey el conde de Monterrey, así como el 22 de septiembre se dijo que el conde de la Laguna tomaría el cargo. Ibidem, pp. 20 I-202. Todavía algunos ańos después se seguiría rumorando el cambio de gobernante. 9. Leticia Pérez Puente, Tiempos de crisis y tiempos de consolidación. La catedral metropolitana de la ciudad de México, I653-I680, México, Universidad Nacional Autónoma de México/Centro de Estudios Superiores Universitarios/El Colegio de Michoacán/Plaza y Valdés, 2005, pp. I 7 I y ss. Agradezco a Antonio Rubial por darme a conocer este trabajo. 
Mientras tanto fray Payo cumplía con sus funciones y establecía vínculos de poder. En 1675, por ejemplo, mandó celebrar el cumpleaños de Carlos II con una corrida de toros en la que el líder moral de la nobleza criolla, el conde de Santiago, Fernando Altamirano de Velasco y Castilla, salió con varios lacayos. ${ }^{\text {Io }}$ Poco después, en enero de i676, el conde de Santiago fue nombrado corregidor de la ciudad, con lo que principió una estrecha relación de trabajo entre ambos. ${ }^{I I}$

A principios de 1676 el barco de aviso llegó de España y, entre otras cosas, se supo que el rey "nombró por su caballerizo mayor al almirante [de Casti1la] y sumiller de cortina, al Duque de Medinaceli y de Alcalá". ${ }^{22}$ En su reseña de la noticia, Robles se aseguró de utilizar el segundo título del duque, pues lo relacionaba familiarmente con el virrey fray Payo: Juan Francisco de la Cerda, VIII duque de Medinaceli y VI duque de Alcalá de los Gazules, era el heredero de los títulos familiares del arzobispo-virrey. ${ }^{13}$ Sin duda la cercanía del duque de Medinaceli con el rey, recién estrenado en su gobierno personal, aunque la noticia no había llegado aún a la Nueva España, favorecía a fray Payo, dándole razones para sentirse afianzado en su cargo.

En octubre llegó un nuevo aviso donde se señalaba que Carlos II había asumido el mando al alcanzar la mayoría de edad y que no había virrey electo. ${ }^{14}$ Junto con las noticias llegó una cédula "para que se le pague el salario como virrey a SE" IS Entonces fray Payo se apresuró a organizar grandes fiestas en honor al rey, en las que el conde de Santiago sería de gran ayuda e incluso correría con algunos de los gastos para hacerlas verdaderamente espectacula-

Io. Robles, op. cit., p. I 86.

I I. Robles cuenta que el I 3 de enero el conde de Santiago debía tomar posesión de su cargo en el real acuerdo, pero no lo hizo "por querer entrar con espada". El I 7 del mismo mes se le tomó finalmente el juramento ante fray Payo. Seguramente le concedieron su deseo. Ibidem, pp. I87-I9 I y I96.

I 2. Ibidem, p. I 88 .

I3. Juan Francisco de la Cerda (I637-I69I) llegó con el tiempo a ser el "hombre fuerte" del gobierno de Carlos II, pero cayó en desgracia a poco de que el rey se casara con María Luisa de Orleans. Kamen, op. cit., p. 373.

I 4. En abril Robles apuntó que la noticia de que el rey había tomado el gobierno el día de su cumpleaños número I4 (el 6 de noviembre de I675) ya había llegado a Guatemala, no así el aviso para la Nueva Espańa que había salido en enero de i676. Dicha noticia se confirmó con la llegada del aviso el I de octubre. Robles, op. cit., pp. I96-197 y 203-204.

I 5. Ibidem, pp. 203-204. No obstante que su sueldo ascendió a los reglamentarios 20000 ducados de plata anuales, la cédula señalaba que se trataba del "virrey en interin". Pérez Puente, op. cit., p. I77. 
res. ${ }^{16} \mathrm{El}$ esplendor de los festejos se comparó sólo con el del propio fray Payo, que quizá se situó en aquel tiempo en el mejor momento de su carrera política.

Antonio de Robles reseńó brevemente las conmemoraciones que organizó el virrey, cercanas ya al nuevo cumpleaños del monarca. El 9 de octubre se pregonaron luminarias; el 16 de noviembre se comenzaron a jugar seis días de corridas de toros; el 25 salió una máscara de caballeros formada por cerca de 250 hombres, de las mejores que se habían dado en México según el diarista, misma que se repitió el siguiente día culminando con carreras de caballos. El 8 de diciembre tuvo lugar la fiesta de los gremios, en que salieron cinco carros, llevándose la gala el de los plateros. Fue mejor aún la repetición del siguiente día, cuando salió a caballo un joven que figuraba al rey, con 60 soldados de las tres guardias del palacio real. El costo de los carros ascendió a 3750 pesos. ${ }^{17}$

Alonso Ramírez de Vargas narró las fiestas en un texto dedicado al arzobispo-virrey: Sencilla narración, alegórico fiel trasumpto, dibujo en sombras y diseño escaso..., publicado en $1677,{ }^{18}$ crónica pormenorizada de toda la celebridad que incluye la descripción de los carros de la procesión gremial, cada uno de gran belleza y complejidad. ${ }^{19}$ Entre los aparatos de gremios nos llama la atención el que dedicaron a Marte los pintores y los mercaderes de plaza,

I6. En su crónica, el poeta Ramírez de Vargas puntualizó la gran ayuda que le dio el conde de Santiago a fray Payo en la organización de las fiestas. El corregidor: "Envió llamar a los veedores [de los gremios] y con la afabilidad que acostumbra — heredada de su nobilísima sangre— hízoles la proposición con razones eficaces por suaves, previniéndoles que aquella insinuación no la abrazaran como precepto sino como incentivo de su lealtad; y que midiéndose con sus caudales hiciesen lo que pudiesen como fieles vasallos, ayudando los gremios ricos a los más pingües, y no estando con actitud de alguno dellos por descaecido en los accidentes del trato, que, desde luego, lo daba por escusado; y que sería acción que tendría en la memoria toda la vida, para en lo que pudiese recompensarla; ofreciéndoles para alentarlos jaeces, caballos, tiros de mulas, vestidos y cuanto pudiera servir de su casa que fuese a propósito para el intento". Ramírez de Vargas, op. cit., pp. 232-233.

17. Robles, op. cit., pp. 205-206.

I8. Del poeta Alonso Ramírez de Vargas se conservan pocas noticias — reseñadas por Dalmacio Rodríguez-, quien señala en Texto y fiesta..., op. cit., pp. 70-74, que fue criollo, militar y funcionario público.

I9. El poeta dejó además el recuerdo de la obra de teatro que se celebró en Palacio. Esta comedia, titulada El lindo don Diego, se escenificó en Palacio el día del cumpleaños del rey. Con ella se presentaron los "prevenidos adherentes, que la rodearon de discantes [concierto de música de cuerda], músicas, bailes, entremeses, mojigangas etc.”. Dalmacio Rodríguez apunta que Agustín Moreto y Cabańa fue el autor de dicha comedia, impresa en I662 por vez primera. Ramírez de Vargas, op. cit., p. 207. 


\section{$76 \quad$ PAULA MUES ORTS}

pues hacía gala de una ostentación muy distinta de la riqueza material: el orgullo profesional de los artífices del pincel. No obstante que el tema del carro les era lejano, los artistas encontraron la manera de exhibir a través de él, pública y claramente, el alto concepto que tenían de su profesión, moralizadora y educadora de príncipes y reyes, y de mostrar a la pintura como arte liberal. Ningún otro carro buscó mandar un mensaje parecido acerca de los demás oficios (nueve) ni llamar especialmente la atención a la máxima autoridad del reino. ${ }^{20}$

\section{Águila agustina de cuna sevillana y educación cortesana}

Al terminar de pasar el carro de los pintores y mercaderes, un joven que personificaba a Marte y que llamó a fray Payo "águila agustina” le dirigió las loas escritas por el poeta Josef Ramírez Dorantes ${ }^{2 \mathrm{I}}$ para completar, con palabras y en una especie de emblema vivo, las imágenes belicosas. Una lectura detallada de la descripción del carro y los poemas explicatorios parece indicar que los pintores sospechaban que Enríquez de Ribera poseía la cultura necesaria para comprender los alcances de la imagen que le habían presentado.

20. El antecedente novohispano más directo identificado hasta ahora de un festejo donde sus creadores aludieron a la pintura con orgullo fue la recepción que ofreció al virrey duque de Alburquerque en 1653 en el ayuntamiento de la ciudad de México, en cuyo arco se figuró a Apeles pintando al nuevo virrey. La catedral, a su vez, patrocinó otro arco que también considero significativo, pues aludió al virrey por medio de Marte. Francisco de la Maza, La mitología clásica en el arte colonial de México, México, Universidad Nacional Autónoma de México-Instituto de Investigaciones Estéticas, I968, pp. 77-8 I y 82-88. En Lima, virreinato del Perú, se dio un antecedente aún más cercano al caso analizado en esta investigación, pero es difícil saber si los pintores novohispanos tuvieron noticia de él. Se trató de un carro alegórico que salió en honor al nacimiento del príncipe Felipe Próspero en I659. Los pintores, escultores y arquitectos fueron los protagonistas de la fiesta y en el carro "de las artes" se figuró a la Pintura como matrona. Según Luis Eduardo Wuffarden, para dicha alegoría los pintores se basaron en los grabados de Vicente Carducho, tal como propongo que hicieron los pintores novohispanos en I 676. Los artistas limeños mencionaron en su programa simbólico la función de los pintores en la educación del príncipe. Luis Eduardo Wuffarden, "La ciudad y sus emblemas: imágenes del criollismo en el virreinato del Perú", en Los siglos de oro en los virreinatos de América I 550-I700, Madrid, Sociedad Estatal para la Conmemoración de los Centenarios de Felipe II y Carlos V, I999, pp. 74-75. Agradezco a Rosario Granados la mención a esta referencia.

2I. No he podido encontrar datos biográficos de este poeta. 
Payo o Pelayo nació en Sevilla hacia I6I2,22 hijo ilegítimo de Fernando de Afán de Ribera y Enríquez (I583-1637), III duque de Alcalá de los Gazules y $\mathrm{V}$ marqués de Tarifa, y Leonor Manrique de Lara, dama también de origen noble. Su padre

había sido adelantado mayor de Andalucía, gobernador de Milán, virrey de Cataluña, Nápoles y Sicilia; además era pintor aficionado, un gran bibliófilo y latinista distinguido, que dedicaba su tiempo libre a la búsqueda de antigüedades [...], y se disputaba con otras grandes casas el mecenazgo de talentos. ${ }^{23}$

La más notable de estas contiendas por el patrocinio artístico fue sin duda la que mantuvo con el conde de Olivares, futuro valido de Felipe IV. Entonces Fernando Afán utilizaba, para convidar a su grupo de protegidos intelectuales, el palacio sevillano que había heredado para remodelar: la Casa de Pilatos. ${ }^{24}$ La historia de dicho palacio es muy ilustrativa de la manera como se conformó la familia Enríquez de Ribera y en particular la personalidad del padre del futuro fray Payo, pero escapa de los límites de esta investigación. Sólo mencionaré, por tanto, los datos más relevantes para esbozar algunas características en torno a la educación del personaje que nos ocupa.

A los 17 años de edad, Fernando Afán de Ribera comenzó una batalla legal en contra de su madre por el control de la fortuna familiar, pleito que ganó en

22. Algunos autores, como Marita Martínez del Río de Redo, señalan i 604 como el año del nacimiento de Payo Enríquez de Ribera, mientras otras fuentes lo sitúan en I 6 I 2 y aún otras en I622. Leticia Pérez Puente lo coloca en I6I2, retomando quizá a Francisco Sosa. Por los datos seguros de su vida en que coinciden casi todos sus biógrafos, I6 I 2 parece ser el más plausible. Marita Martínez del Río de Redo, "Dos biombos con tema profano”, en Elisa Vargaslugo y José Guadalupe Victoria (coords.), Juan Correa. Su vida y su obra. Repertorio pictórico, México, Universidad Nacional Autónoma de México-Instituto de Investigaciones Estéticas, I994, t. IV, segunda parte, pp. 453-490, en especial el árbol genealógico de la p. 468; Pérez Puente, op. cit., p. I7I; Francisco Sosa, El episcopado mexicano. Biografía de los Ilmos. señores arzobispos de México. Desde la época colonial hasta nuestros días, con una breve noticia biográfica y un apéndice de Alberto María Carreño, México, Jus, I962, t. II, p. I9 [primera ed. I877].

23. Pérez Puente, op. cit., p. I7 I.

24. Al parecer, Olivares se propuso desbancar a Enríquez de Ribera como principal mecenas y coleccionista en Sevilla. Aunque la relación entre ambos fue bastante estrecha, terminó enfriándose e incluso se cree que Fernando Afán se unió años más tarde a los opositores del valido. John $\mathrm{H}$. Elliott, El conde-duque de Olivares, Barcelona, Grijalbo-Mondadori, I998. 
I605. ${ }^{25}$ Incluso antes de que el litigio se resolviera a su favor, el duque de Alcalá realizó importantes modificaciones al palacio, que incluyeron ampliaciones y grandes ciclos decorativos. Así, Francisco Pacheco terminó de pintar en I604 varios techos del palacio con temas mitológicos, basados principalmente en los emblemas de Alciato. ${ }^{26}$

La habitación principal que decoró Pacheco, destinada a recibir invitados y ostentar la gran colección artística de Alcalá, era llamada "camarín grande". En este camarín estaban casi todas sus esculturas, principalmente bronces pequeños y yesos de varios artistas, entre los cuales había piezas antiguas y un número importante del escultor italiano Gian Bolonia. ${ }^{27}$ Musas pintadas y vaciadas en bronce, dioses mitológicos como Apolo, Palas y Venus, sátiros y ninfas, así como retratos familiares, de personas reales y de filósofos como Heráclito y Demócrito, ${ }^{28}$ convivían con paisajes, escenas cotidianas, figuras de animales, urnas antiguas y varios bufetes, algunos destinados a guardar dibujos. ${ }^{29} \mathrm{Lla}-$ man la atención algunas piezas que el duque tenía en esta habitación, como "un ydolo de plata con un pescado al hombro y su pedestal de las Yndias" y "dos Ymagenes de pluma de las Yndias", las cuales quizá estaban en la familia desde tiempos de su abuela Juana Cortés, hija de Hernán Cortés, además de varios lienzos sin pintura, un pincel antiguo y "un caballete de pintar embutido de diversas maderas", que tal vez usaba el duque en sus ratos de ocio.

25. Vicente Lleó Cañal desarrolla la historia de la Casa de Pilatos, "Los techos pintados de la Casa de Pilatos”, en Velázquez y Sevilla, Sevilla, Junta de Andalucía/Consejería de Cultura, I999, pp. I73-I8I.

26. Para la historia y las interpretaciones de la pintura de los techos en la Casa de Pilatos, además del texto señalado arriba, véase Francisco Pacheco, Arte de la pintura, Bonaventura Bassegoda i Hugas (ed., pról. y notas), Madrid, Cátedra, I990, pp. 726-727; Rosa López Torrijos, La mitología en la pintura española del Siglo de Oro, Madrid, Cátedra, I995, pp. I 29-I 37, y Santiago Sebastián, Emblemática e historia del arte, Madrid, Cátedra, I995, pp. 76-80, entre otros.

27. Los detalles del duque de Alcalá como mecenas y coleccionista se describen por Jonathan Brown y Richard L. Kagan, "The Duke of Alcala: His Collection and Its Evolution", The Art Bulletin, Nueva York, The College Art Association of America, vol. 69, núm. 2, junio de I987, pp. $23 \mathrm{I}-255$.

28. Estos dos óleos son del pincel de José de Ribera.

29. El inventario analizado y reproducido por Brown y Kagan (art. cit.) describe con todo detalle las piezas que se exponían en el camarín grande. Las 2 I 4 entradas del inventario, muchas de ellas señalando varias piezas, proponen que lejos de verse como hoy día, limpia y amplia, la galería estaría invadida de piezas, como algunas de las que representaron Teniers y Jan Brueghel para difundir las colecciones de sus patronos. 
Se cree que esta sala sirvió de escenario a una de las más famosas academias poéticas de Sevilla, donde era frecuente encontrar al propio Pacheco entre literatos y estudiosos de la antigüedad clásica. ${ }^{30}$ El pintor sevillano, en efecto, estuvo estrechamente ligado a Fernando Afán, con quien trabajó en repetidas ocasiones y entabló una amistad cercana. ${ }^{3 \mathrm{I}}$ Los techos que pintó para él fueron hogar de personajes mitológicos como Hércules, Dédalo, Ícaro, Astrea y Faetón, y tenían la clara intención de servir como modelo al joven duque pues le mostraban "con heroica virtud el arduo camino de la gloria", según una de las inscripciones en latín que acompañaba a Hércules. ${ }^{32}$ A cambio, el duque mostró en distintas formas su reconocimiento al saber y la calidad del pintor, como cuando escribió una carta en defensa de la propuesta iconográfica de Pacheco para la crucifixión de Cristo, ${ }^{33}$ o en el trato de hombre de respeto que el aristócrata brindó al artista, mismo que Pacheco recordó en su tratado de la siguiente manera:

no da las letras el cabal conocimiento desta arte [la pintura], si no se frecuenta la comunicación de un grande artífice, en cuya presencia es cordura [para los nobles] moderar sus pareceres y estar sujetos a ellos y no tener a todos los pintores por ignorantes. Llegó a tanta, tal vez, su confianza que se ha atrevido algún docto a quitarme el pincel de la mano para manifestar sus sentimientos, y yo he tenido la flema para

30. Acerca de la academia del duque de Alcalá, hay desacuerdos entre los estudiosos de la pintura española. Mientras que algunos, como Lleó Cañal, Brown, Kagan, Elliott y Sebastián, aceptan que se reunieron en ella varias figuras importantes de la Sevilla del momento, otros, como Bassegoda i Hugas, seńalan que no hay datos concretos de la academia y que se ha exagerado la importancia de la relación entre Pacheco y el duque de Alcalá.

3 I. Pacheco, en su tratado Arte de la pintura, mencionó por lo menos en cinco ocasiones al duque de Alcalá, lo cual trasluce una relación, a mi parecer, bastante cercana entre ambos. Jonathan Brown habla de ésta cuando describe el ambiente académico sevillano. Llaman la atención las referencias en que Pacheco señala que sirvió como asesor de pintura de la colección del duque. Pacheco, op. cit., en especial las pp. I87, I92-193, 217, 51 I, 545, 549, 71 3 y 726-727. Por su parte véase Jonathan Brown, Imágenes e ideas en la pintura española del siglo XVII, Madrid, Alianza, I988, en especial las pp. 48-52 y I02-I I 2.

32. Lleó Cañal, op. cit., p. I77.

33. Fernando Afán, tras una visita al taller del artífice, quedó sorprendido con la propuesta de Pacheco de que a Cristo se le había crucificado con cuatro clavos, iconografía que causó polémica en Sevilla. Cuando fue virrey en Cataluña, sin embargo, escribió y publicó el pequeño tratado Del título de la cruz para defender la propuesta de Pacheco. Brown y Kagan señalan que se publicó en Barcelona, en I6I9; Pacheco y Bassegoda, que se escribió en I622. Brown y Kagan, op. cit., p. 234; Bassegoda en la introducción, op. cit., p. 29; Pacheco, op. cit., pp. 726-727. 
sufrirlo. Mucho me edificaba, en el rendimiento y modestia en esta parte, el maestro Fray Juan Farfán y un príncipe tan grande y, también, entendido como el Duque de Alcalá. ${ }^{34}$

Así, las referencias clásicas, como el Ovidio moralizado, el Emblematum Liber de Alciato, las alegorías plásticas y la erudición poética y pictórica, fueron elegidas para que las practicara el padre de Payo como virtudes del caballero. Este ambiente tan estimulante, sin embargo, no podía ser heredado cabalmente a Payo a causa de su condición de hijo ilegítimo. Como su suerte le impedía ser el futuro heredero de los títulos del ducado de Alcalá de los Gazules y el marquesado de Tarifa, se le destinó desde pequeño a la carrera eclesiástica (fig. I).35

A los I 3 años Payo fue enviado a la orden de San Agustín en el real convento de San Felipe de Madrid para que permaneciera cerca del medio cortesano. Su padre, en su estancia diplomática en Roma en I625, logró del papa Urbano VIII una dispensa de ilegitimidad para Payo, con la cual se le abrirían las puertas de cualquier prebenda eclesiástica. ${ }^{36}$ Todo parece indicar que Fernando Afán cuidó de su hijo, y es factible imaginar que éste sabía de las actividades artísticas y eruditas de su progenitor. Tal vez incluso conoció algunos personajes influyentes de Sevilla y de Madrid con los que éste trataba, como los pintores Francisco Pacheco y Vicente Carducho. Este último también recordó gratamente al duque en su tratado, al hablar de la pintura cortesana:

Y ya vemos las más doctas plumas desveladas en sus alabanzas; los señores, y toda la nobleza la alaban, ensalzan, y gustan della, y de que sea singularmente buena [...] Afiance mi opinión [...] el Duque de Alcalá conocido en estos siglos por sus clarísimos títulos, y en Italia por la eminencia de su gobierno en el Principado de Cataluńa, Reinos de Nápoles, y Sicilia; y en particular el honrador de nuestros profesores por singulares modos, procurando, que el adorno de su casa sean valientes Pinturas antiguas, $y$

34. Pacheco, op. cit., p. 545. Las cursivas son mías.

35. Pérez Puente, op. cit., pp. I7 I-I72. Para el árbol genealógico presentado como fig. I, me basé en diversas fuentes, en especial en Marita Martínez del Río de Redo, Leticia Pérez Puente, Vicente Lleó Cañal, Jonathan Brown y Richard Kagan, así como en el folleto La casa de Pilatos.

36. Brown y Kagan, op. cit., pp. 233-234. Estos autores señalan que el duque tenía cinco hijos ilegítimos. Una de sus hermanas - cuyo nombre religioso fue Ana de la Cruz y que vivió en el convento de Santa Clara de Montilla, en Córdoba, España - declaró muchos años después, hacia I679, que tenía visiones místicas. Fray Payo, desde su gobierno americano, le ofreció un apoyo total. Gabriela Sánchez Reyes, "Fray Payo Enríquez de Rivera: promotor de la conciencia criolla a través de la imagen de la Virgen de Guadalupe", ms. inédito. Agradezco a la autora la gentileza de compartir su estudio conmigo. 

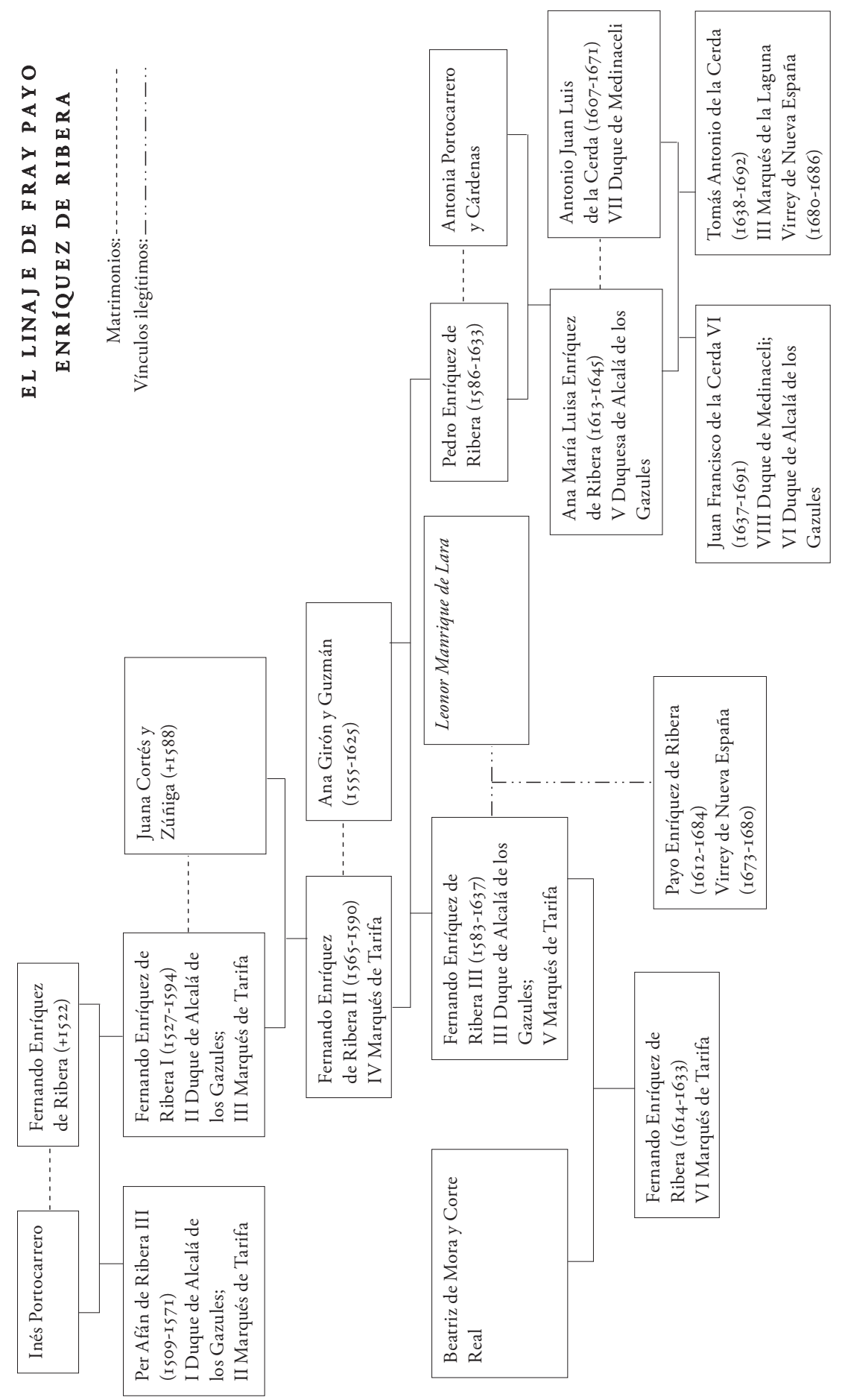

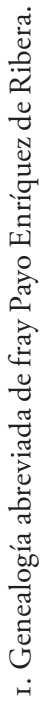


modernas, haciéndola un magnifico Museo de las más preciosas que se han hecho en el mundo a costa de un particular cuidado, y gran tesoro de sus muchas rentas, añadiendo con este virtuoso afecto una piedra brillante a la gloria de su ilustrísima Casa. ${ }^{37}$

Así, la pintura, en el caso de Payo Enríquez de Ribera, probablemente cumplió con la máxima de educar deleitando. ${ }^{38}$

La carrera ascendente de Payo comenzó con su profesión en I628. En I647 se graduó de licenciado y doctor en teología en la Universidad de Sigüenza; tres años más tarde fue prior en Valladolid y hacia I654 definidor de la provincia agustina de Castilla. En I656, mientras se desempeñaba como rector del colegio de doña María de Aragón, en Madrid, fue nombrado obispo de Santiago de Guatemala, cargo que tomó en 1659. De su estancia en su primera mitra americana hay pocos datos, pero destacan entre ellos los que lo dibujan como un hombre interesado en el conocimiento: la introducción de la imprenta en su obispado y la intención de lograr la fundación de la universidad de dicha provincia, para la cual incluso eligió a los primeros catedráticos. ${ }^{39}$

Hacia 1668 se le designó obispo de Michoacán, pero a la muerte del recién electo arzobispo de México, Marcos Ramírez de Prado, fray Payo fue promovido a su cargo. Sus grandes cualidades administrativas y políticas se confirmaron casi de inmediato ${ }^{40}$ en enfrentamientos como el que sostuvo con los regulares franciscanos y agustinos por la administración de las parroquias de indios. ${ }^{4 \mathrm{I}}$ Por otro lado, fray Payo también afianzó su poder en el cabildo catedralicio, enfrentándose por ello al propio virrey, el marqués de Mancera. El cabildo eclesiástico, al momento de su posesión, estaba fuertemente divi-

37. Vicente Carducho, Diálogos de la pintura. Su defensa, origen, esencia, definición, modos y diferencias, Francisco Calvo Serraller (ed., pról. y notas), Madrid, Turner, 1979, pp. 443-444 [primera ed. 1633] (las cursivas son mías). Por supuesto, Carducho exageró las bondades del duque como gobernante, pues, a diferencia de su hijo Payo, muchas noticias señalan que Alcalá no fue buen político.

38. Quizá la muerte prematura del heredero legítimo del duque de Alcalá en I633, llamado Fernando como su padre, influyó para acrecentar la suerte de Payo.

39. Fray Payo también apoyó en forma directa a Pedro de Betancur, fundador de los religiosos betlemitas que poco después se trasladaron a México. Pérez Puente, op. cit., pp. I7I-I74.

40. Francisco Sosa señala que la entrada pública como arzobispo se realizó en diciembre de I 670 debido al retraso de la llegada del palio, aunque el cargo había sido asumido desde junio de I668. Sosa, op. cit., pp. 20-2 I.

4I. Antonio Rubial, "La mitra y la cogulla. La secularización palafoxiana y su impacto en el siglo XVII”, Relaciones, El Colegio de Michoacán, vol. XIX, núm. 73, invierno de I998, pp. 239-272. 
dido por pugnas de poder, a lo que Payo respondió con una determinación férrea por lograr la unidad entre los miembros de la corporación. Para ello mostró siempre una actitud de respeto y consideración al cabildo, anteponiendo el interés de este cuerpo a las voluntades individuales. Como bien lo ha narrado Leticia Pérez Puente, este manejo de su autoridad logró cohesionar al cabildo eclesiástico, y con ello obtuvo un poder y una relevancia que no había tenido desde hacía muchos años. ${ }^{42}$ La habilidad política de fray Payo se mostró además en el favorecimiento de devociones locales y en la protección a sus promotores, algunos de ellos vinculados también al cabildo. Así, Enríquez de Ribera se involucró activamente en la promoción del culto a la Virgen de Guadalupe comenzando en i675 la construcción de la calzada al santuario, y no dudó en autorizar el famoso milagro de los panecitos de santa Teresa, obrado por manos de la hermana del deán de la catedral metropolitana, Juan de Poblete. ${ }^{43}$

Si como arzobispo ya había logrado consolidar su figura, cuando recibió el nombramiento de virrey en 1673 las dudas que pudieron existir acerca de su fortaleza se disiparon. El ahora arzobispo-virrey logró definitivamente la unificación del cabildo eclesiástico, mientras se acallaban los pleitos con los regulares. Lo único que podría mermarle relieve era su situación de virrey interino, por lo que los rumores de la venida de nuevos gobernantes iniciados por sus detractores fueron comunes. Como ya se señaló, en i676, al otorgársele sueldo de virrey y confirmarse la cercanía del duque de Medinaceli — su sobrino segundo y heredero de los títulos de su padre- con el nuevo monarca, fray Payo se colocó en una posición realmente firme. Las fiestas en honor a Carlos II no pudieron llegar en momento más oportuno: la exhibición de lealtad también lo era de su propio poder. En este contexto, la ostentación de la pintura como arte liberal era quizá una osadía que se permitieron los artífices por el perfil humanista y familiar del gobernante. Sabrían, tal vez por los tratados de Pacheco y de Carducho, que su padre había sido un gran mecenas y pintor aficionado, quien además había mostrado predilección por la pintura y apoyado a los artistas.

42. El fortalecimiento del cabildo eclesiástico gracias a la habilidad política de fray Payo es el tema primordial que desarrolla Leticia Pérez Puente en su excelente trabajo ya citado.

43. Gabriela Sánchez Reyes, op. cit., ha estudiado al arzobispo-virrey desde el punto de vista de las devociones novohispanas, destacando la guadalupana sobre las demás, así como las ligas que estableció con un grupo de criollos importantes en la segunda mitad del siglo XVII. 


\section{En superior lugar estoy sentada}

Vicente Carducho y Francisco Pacheco defendieron y cultivaron la intelectualidad, liberalidad y nobleza de la pintura por medio de sendos tratados teóricos: Diálogos de la pintura, de 1633, de Carducho, y Arte de la pintura, de Pacheco, publicado póstumamente en 1649 pero escrito en un periodo de casi 30 años. Con ellos se sumaron a una tarea que desde los albores del siglo XVII había comenzado a ser activa: la defensa del arte, y, con ella, la de la condición de sus practicantes. ${ }^{44}$

En el siglo Xvi la pintura empezó a ganar la atención de monarcas y eclesiásticos, quienes comenzaron a formar verdaderas colecciones artísticas. Ello no implicó, sin embargo, un cambio inmediato en la conceptuación social de los artistas, pues la mayoría de las veces los patronos los veían como artesanos de poca valía; un trato como el que el duque de Alcalá dio a Francisco Pacheco era realmente desusado. ${ }^{45} \mathrm{El}$ prejuicio que hacía que al arte se le viera aún como sinónimo de técnica, que se le considerara repetitivo y mecánico, fue un obstáculo muy grande para la ascensión de los artistas en un mundo donde la jerarquización social dependía de la sangre, la riqueza y la práctica de una actividad "liberal", inmaterial o intelectual.

Los artífices, en general, y en particular los del pincel, buscaron adaptar las teorías que hacían de sus creaciones labores tan importantes e intelectuales como las de los poetas, los científicos y los practicantes de las consagradas

44. El proceso de la pintura española hacia una nueva conceptuación como arte liberal ha sido tratado en muchos estudios. Entre los más importantes deben señalarse los siguientes: Francisco Calvo Serraller, Teoría de la pintura del Siglo de Oro, Madrid, Cátedra, I99I; Julián Gállego, El pintor. De artesano a artista, Granada, Diputación Provincial de Granada, I995; Karin Hellwig, La literatura artística española del siglo XVII, Madrid, Visor (La Balsa de la Medusa, I02), I999; Juan José Martín González, El artista en la sociedad española del siglo XVII, Madrid, Cátedra (Manuales de Arte Cátedra), I993. Para el ámbito novohispano, poco estudiado aún, véase Juan Miguel Serrera, "La defensa novohispana de la ingenuidad de la pintura", Boletín de la Real Academia de Bellas Artes de San Fernando, Madrid, segundo trimestre de I995, núm. 8I, pp. 277-288; Paula Mues Orts, La libertad del pincel. Los discursos sobre la nobleza de la pintura en Nueva España, Universidad Iberoamericana-Departamento de Arte, 2008; y "Merezca ser hidalgo el que pintó lo santo y respetado: la defensa novohispana del arte de la pintura", en Jaime Cuadriello (ed.), $E l$ divino pintor: creación de María de Guadalupe en el taller celestial, México, Museo de la Basílica de Guadalupe, 200I, pp. 29-59; Mina Ramírez Montes, "En defensa de la pintura. Ciudad de México, I753”, Anales del Instituto de Investigaciones Estéticas, vol. XXIII, núm. 78, 200 I, pp. I03-I 28.

45. Véase la n. 34. Este desprecio es el que Pacheco contrasta allí con la conducta y el trato honroso que le brindó el duque de Alcalá. 
artes liberales. En este proceso encontraron el apoyo de varios juristas y mecenas, dispuestos a defender sus intereses. Ésta fue la manera en que los pintores fueron granjeándose el favor de personajes sabios y respetados, quienes, al igual que ellos, valoraban las creaciones artísticas como portadoras de mensajes, como símbolos de ideas, como vehículos del conocimiento y la moral.

Este proceso comenzó por el conocimiento de muchas ideas surgidas en los principales centros artísticos italianos del siglo XVI, así como por su adaptación a las realidades locales tradicionales y a las nuevas condiciones artísticas ligadas a la centralización del poder. Pintores, poetas y juristas describieron el origen celestial de la pintura con Dios como su primer practicante; el uso inmemorial del arte para lustre de los monarcas; su función en la guerra para alentar a los soldados o inmortalizar las victorias y el provecho que se sacaba de la pintura religiosa al retratar a los santos o a las personas divinas; o bien, narraron cómo los nobles y reyes descansaron de sus obligaciones en los pinceles; cómo los santos se valieron de las imágenes para sus fines o incluso las crearon; cómo Dios favoreció algunas de ellas con milagros, y cómo los hombres sabios y poderosos siguieron su ejemplo y valoraron la pintura por su intelecto y no por su materialidad.

Estos argumentos fueron comunes entre quienes escribieron para defender a los pintores del pago del impuesto de la alcabala, que gravaba toda operación de compraventa..$^{46}$ Para los artífices, este impuesto, además de ir en contra de su economía, significaba que su actividad era vista como la de cualquier productor, desde un curtidor hasta un cerero, principio con el cual estaban en desacuerdo.

Las ideas expuestas fueron discutidas por artistas, poetas y patronos en distintos ámbitos, pero las academias informales cada vez se vieron más favorecidas para ello. Uno de los principales propulsores de estos grupos fue Vicente Carducho, quien desde muy temprano el siglo Xvir quiso que el rey elevara la pintura, por medio de su academia, al lugar desde el que ella juzgaría la pertinencia de las actividades artísticas cortesanas. Como el mismo Carducho cuenta en su tratado, los primeros opositores fueron los artistas de varios gremios, pues no quisieron verse sojuzgados por la pintura. ${ }^{47}$ Por su parte, la academia

46. Es importante señalar que el impuesto de la alcabala en España fue sustantivamente más alto que el novohispano, por lo cual quizá la reacción en contra del mismo fue menor de este lado del océano. Mientras que en España se cobró io por ciento, en la Nueva España pasó de 2 por ciento a finales del siglo Xvi a 6 por ciento en el xviII. Por un breve periodo subió hasta 8 por ciento, pero volvió a bajar a 6 .

47. Carducho, op. cit., pp. 440-443. 
de Francisco Pacheco tuvo más éxito que la del pintor de origen florentino, probablemente porque no intentó centralizar las funciones de árbitro y juez y, más que ello, porque se amoldó a las formas tradicionales de trabajo y legalización del mismo vigentes en su tiempo, como los gremios. Después de estas academias hubo muchas que tendían cada vez más a centrar sus tareas en la pintura y avanzaban lentamente en cuanto a su concepción como verdaderas instituciones educativas.

Arma común en esta lucha por elevar este arte fue la teoría pictórica nacida en el Renacimiento italiano, que utilizó una idea atribuida por Plutarco a Simónides pero fijada por Horacio: Ut pictura poesis, buscando adaptar la teoría poética a la pintura. ${ }^{48}$ En esta comparación fue usual decir que la pintura era muda mientras la poesía ciega, pero ambas copiaban a la naturaleza. La pintura, de esta manera, iría haciendo realmente suyo un corpus teórico del que carecía y que le otorgaría identidad. Entonces surgió la emblemática como el lenguaje que mejor expresaba las bondades del binomio poesía-pintura, al unir palabra e imagen con el fin común de reflexionar acerca de la naturaleza humana y las maneras para guiarla moralmente. Los pintores cultos reconocieron rápidamente en esta formulación una prueba más de la utilidad e intelectualidad de la pintura. Quizá por ello el lenguaje emblemático se amplió para englobar obras que sí privilegiaban su plasticidad, llegando incluso a suprimir el texto, pero conceptualmente derivaban de los emblemas.

Vicente Carducho fue pionero en el uso de este lenguaje emblemático al incluir en sus Diálogos de la pintura, escrito en forma de coloquios entre un maestro y su discípulo, ocho grabados que se corresponden con ocho poemas, cada uno aludiendo al otro. ${ }^{49} \mathrm{El}$ que cierra el diálogo cuarto señala justamente la complicidad entre la pintura y la poesía, como indica Javier Portús. ${ }^{50}$ En el coloquio titulado De la pintura teórica, de la práctica, y simple imitación de

48. Rensselaer Lee, Ut pictura poesis. La teoría humanistica de la pintura, Consuelo Luca de Tena (trad.), Madrid, Cátedra, I 982.

49. Cito el único trabajo que conozco acerca de los grabados de Carducho: George Kubler, "Vicente Carducho's Allegories of Painting", The Art Bulletin, Nueva York, The College Art Association of America, vol. 47, I965, pp. 438-445. Quizá no se han vuelto a estudiar porque la edición del tratado de Carducho realizada por Francisco Calvo Serraller — que hasta ahora sigue siendo la única disponible en bibliotecas — reprodujo las láminas de manera errónea, omitiendo una, repitiendo otra y ubicando dos más donde no les correspondía. Carducho, op. cit.

50. Javier Portús Pérez, "Ut pictura poesis en la España del barroco: una aproximación desde su iconografía”, en José Alcalá-Zamora, Calderón de la Barca y la España del barroco, Madrid, Sociedad Estatal/España Nuevo Milenio/Biblioteca Nacional, 2000, pp. I 8 I-I 82. 
lo natural, y de la simpatía que tiene con la poesía, el tratadista diserta acerca de la relación de estas artes y de cómo el pintor debe atenerse a las leyes del decoro que también sigue el escritor. El poema que lo culmina, de la pluma de Miguel de Silveira, señala que de la naturaleza:

\author{
Son sus imitadoras \\ La Poesía y Pintura en partos rudos, \\ Una en voces canoras, \\ La otra en sombras de pinceles mudos, \\ Tanto su actor imitan, \\ Que usurparle la forma solicitan. ${ }^{5 I}$
}

El grabado que lo complementa es considerado por Kubler una representación única en la historia de la alegoría de la Pintura, pues utiliza una combinación de atributos totalmente original: las alas en sus sienes, la boca amordazada para señalar que es muda y la estatuilla a sus pies, donde también está la máscara que alude a la imitación (fig. 2).52 La pintura bosqueja en un libro, mientras la poesía escribe en un lienzo; así, ambas se complementan.

Respecto a la formulación de Carducho, seguramente muy atractiva para los pintores por su discurso teórico y plástico, Portús apunta que

uno de los principales instrumentos que utilizó para la defensa de la pintura es su comparación con la poesía, que llevó a cabo, como hemos dicho, mediante referencias explícitas y a través de ese medio tan sutil como sugerente de pautar su discurso con estampas y poemas que se complementan perfectamente. ${ }^{53}$

El autor señala que ese recurso fue seguido más tarde por otros escritores en España, sentando un precedente importante que quizá también fue percibido y gustado por los pintores novohispanos, lectores de tratados europeos que querían sentar a la pintura en un lugar privilegiado respecto de las otras artes, como lo hicieron en su carro alegórico dedicado a fray Payo.

5I. Carducho, op. cit., p. 2 I 4.

52. Kubler, op. cit., p. 442.

53. Portús, op. cit., p. I 83. 


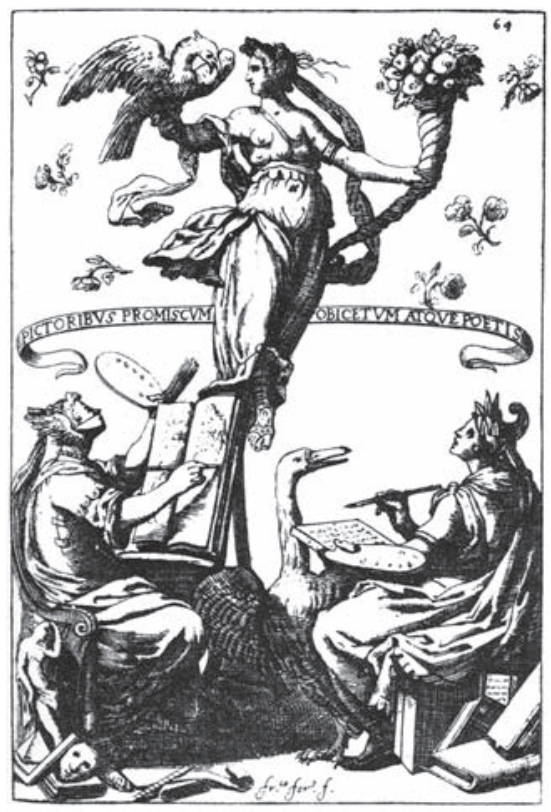

2. Grabado de Francisco Fernández, en el tratado de Vicente Carducho, Diálogos para la historia de la pintura, Madrid, I633, que acompaña el poema de Miguel de Silveira, tomado de Carducho, op. cit. (vid. supra n. 37), p. 215 .

A la vista de todos: alegorías de guerra y pintura

La reseña de la fiesta novohispana en honor a Carlos II trasluce un interesante programa ideológico en su conjunto, pero mucho más evidente en la sección en que se describen los "carros de los gremios". Dalmacio Rodríguez ha señalado cómo el poeta recurrió en su relato al motivo común de las musas, que en diferentes momentos de las fiestas, como la presentación de las comedias, la máscara de caballeros y la de los gremios, salieron a recitar poemas o loas, o a cantar, sintetizando las ideas exhibidas.

Sin embargo, la última parte de la celebración, la de los carros alegóricos, puede ser interpretada en sí misma como un conjunto simbólico, aunque varios poetas trabajaran de manera individual en los motivos y poemas de cada uno. Nueve gremios salieron agrupados en cinco carros, por lo que, para completar el número de siete recomendado para las fiestas, les antecedieron dos: la carroza del virrey, quien "quiso blasonarse de carro triunfal en que celebraba con su generosa presencia el día, paseando por la plaza, mostrando en el agradable rostro el alegría que rebosaba de fina tanto culto, dispensándole la 
seriedad, excitando los ánimos con su estimable complacencia a tan arduas liberales empresas", y una "rodadora giralda" que llevaba los fuegos artificiales para ser encendidos, cual explosiones volcánicas, al finalizar la procesión. ${ }^{54}$

El primer carro de los gremios correspondió a los curtidores, los tratantes de ganado y los panaderos y su tema fue el de la Fama, que acompańaba a Carlos I de Espańa. El segundo, de los sastres, representaba al Sol y sus hijos, con el Tiempo y las Horas. El tercero (el nuestro) se dedicó a Marte, coronado por la Pintura. Le siguió el de los Hijos de América, acompañados de ésta y la Grana, el Oro, la Plata y las Piedras preciosas. Por último, el carro de los plateros, rematado por un joven que representaba al Rey.55 Simbólicamente podía comprenderse que la herencia del nuevo monarca era la fama, ganada por el gran Carlos I, a quien debía emular el segundo Carlos. El Rey, como el Sol, debía garantizar la justicia y la abundancia. En la guerra, Carlos II debía ser como Marte, reuniendo victorias que podía inmortalizar la Pintura. América, en especial el reino de la Nueva España, se rendía con sus riquezas, nuevamente a los pies de la monarquía.

Destaca en este programa la introducción de la Pintura, que resultaba un agregado inesperado al cortejo, como si los artífices se hubieran empeñado en mostrar su arte ante todo el cuerpo del reino. ${ }^{6} \mathrm{El}$ carro de los pintores y los mercaderes de plaza marchaba tras un "bélico rumor" que anunciaba el canto ruidoso de Mavorte. El "escuadrón galanamente horrible" que lo precedía iba a caballo y vestía trajes militares, petos esmaltados, mantos y jo-

54. Siete carros era el número de las fiestas "magnas según Aulo Gelio". Ramírez de Vargas, op. cit., p. 234.

55. Dalmacio Rodríguez dedicó, además de su libro ya citado, otro texto a la misma celebración: "La imagen de Carlos II en la Nueva Espańa: festejos reales en i 676", en José Pascual Buxó (ed.), La producción simbólica en la América colonial, México, Universidad Nacional Autónoma de México-Instituto de Investigaciones Bibliográficas (Estudios de Cultura Literaria Novohispana, I 5), 200I, pp. I73-I9I. En este estudio el autor profundizó en el significado de los carros de los gremios, pero no interpretó el carro dedicado a Marte con relación a la teoría pictórica.

56. Llama la atención que incluso Dalmacio Rodríguez no reconoció, en la descripción del poeta novohispano, la personificación de la pintura. En su libro Texto y fiesta..., multicitado aquí, la figura no le mereció mayor comentario, mientras que en su artículo "La imagen de Carlos II en la Nueva Espańa...", op. cit., p. I 84, no interpreta la figura del carro como la Pintura, sino como una representación sintética de las artes liberales: "Presidía su carro triunfal el dios Marte, representado por 'un armado joven'; a sus pies se rendían dos leones; sobre su asiento había una figura de talla que simbolizaba las artes liberales y una pintura del escudo de armas de 'Su Majestad'". 
yas. Los criados "denotaban los feroces cultos del dios guerrero", vestidos de animales dedicados al bélico planeta: "lobos voraces", "osos membrudos" y "leones rampantes" que abrían paso al carro jalado por unas mulas disfrazadas también de osos.

Para imaginar el carro, propongo una reconstrucción simplificada de su diseño (fig. 3)..$^{57} \mathrm{La}$ "sencilla narración" del poeta permite reconocer el uso del lenguaje emblemático en su mensaje, aunque no lo describiera puntualmente. El trasfondo del aparato era el futuro, augurando el buen gobierno, la abundancia y las victorias militares. Su tono general parece venir de Diego de Saavedra Fajardo y su difundido libro Idea de un príncipe político cristiano, publicado por primera vez en $1640.5^{58}$

En cuanto al sustrato iconográfico, el carro de los pintores y los mercaderes coincide bastante con las recomendaciones de Cesare Ripa para dicho asunto. Según él: "Se representa a Marte, desde los tiempos antiguos, en figura de un hombre de feroz y terrible aspecto [...] de coraza, toda labrada con monstruos espantosos, cubriéndole la cabeza con un yelmo que tiene al pájaro Pico por cimera [...] y va sobre un Carro tirado por dos lobos rapaces". Como compañeros del dios podían aparecer el furor y la impiedad. "Tiene a Pico por cimera, por estar dedicado este pájaro al dios Marte, a causa de su afilada y puntiaguda cabeza, en la que siempre confía cuando lucha contra los demás animales", en tanto los lobos se le atribuyen "por estar estos animales dedicados a Marte, mostrando así la insaciable avidez de los que siguen a los ejércitos, en todo semejantes a dichas fieras". 59

Los patrocinadores novohispanos agregaron al cortejo de Marte los osos y los leones, quizá por su fuerza, y modificaron o le añadieron otros elementos. Al frente del aparato novohispano se figuró un emblema por medio de un Grifo que iniciaba su tarjeta diciendo: "Pico soy, ave rey, deidad valiente, / a quien dio cetro Italia y aras Roma". ${ }^{60}$ Aunque el pájaro Pico, relacionado con

57. Iván Escamilla realizó el bosquejo de esta propuesta, por lo que le estoy agradecida.

58. La segunda edición es de Milán, I642. El libro fue dedicado a Baltasar Carlos, quien hubiera sido el esposo de Mariana, madre de Carlos II, y que a fin de cuentas fue su difunto hermano.

59. Cesare Ripa, Iconología, Madrid, Akal, tt. I y II, 2002, p. I68.

6o. El epigrama completo decía: "Pico soy, ave rey, deidad valiente, / a quien dio cetro Italia y aras Roma; / igual a Marte en culto reverente; / ave de amor que dura al aire doma, / y del Marte español culto valiente / luego que a mi presencia se le asoma; / no de Aris griego la soberbia entendida, / de quien fui igual deidad, hacerme ofrenda". Ramírez de Vargas, op. cit., p. 246. 


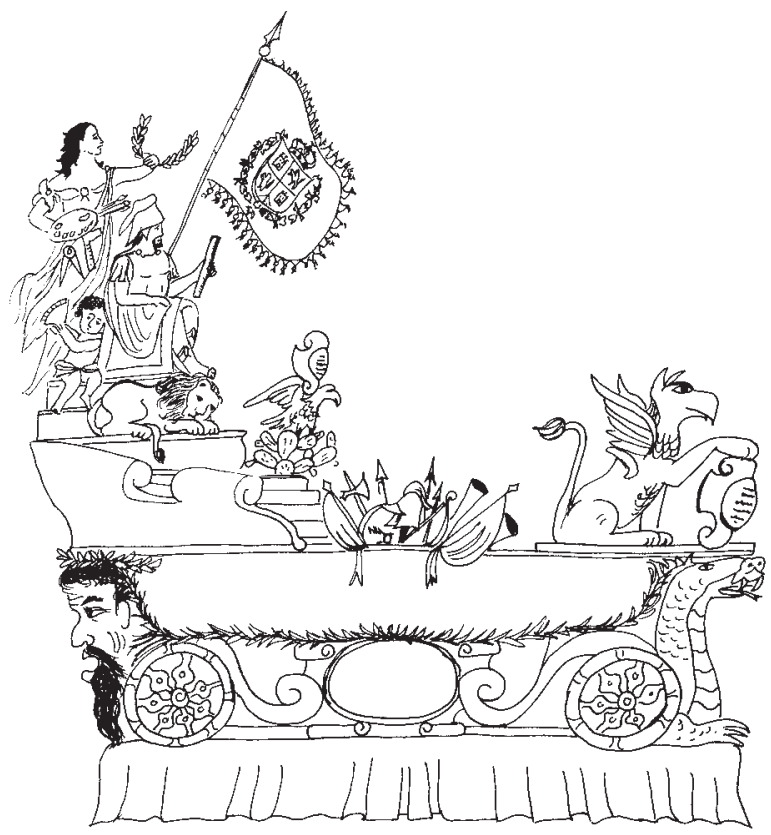

3. Reconstrucción simplificada del carro de los pintores y mercaderes de plaza, basada en la descripción del poeta Alonso Ramírez de Vargas en su libro Sencilla narración, alegórico fiel trasumpto, dibujo en sombras y diseño escaso..., México, impreso por la viuda de Bernardo Calderón, I677. Dibujo: Iván Escamilla González.

las prácticas adivinatorias, ${ }^{6 \mathrm{I}}$ se correspondía bien con el mensaje propiciatorio del carro y con las recomendaciones de Ripa, fue suplantado por un Grifo, quizá porque al ser un pájaro pequeño, "verdes y amarillas las plumas", ${ }_{2}$ no concordaba con el aspecto feroz del conjunto. En cambio, el Grifo, mezcla de león y águila, se ajustaba a él perfectamente al profetizar la importancia de Carlos II, el Marte español, y adelantaba su consagración a él.

6I. Dalmacio Rodríguez, en Ramírez de Vargas, op. cit., p. 246, n. I75.

62. Juan de Arfe (I 535-I603), en el tercer libro de su Varia commensuración (I 587), dedicado a los animales, señala: "Pico es ave pequeña, y verdes y amarillas las plumas; tiene los pies como papagayo, y enfrena la cabeza en su ordinaria postura; tiene en todo una ochava de vara de alto". Juan de Arfe y Villafañe, Bestiario [libro tercero de la Varia commensuración], Isabel Muñoz Jiménez (ed.), s.l., Medusa, 2002, p. Ioo. 
La "plaza de armas" del carro, formada por brazaletes, trompas, escudos, morriones, flechas, lanzas y piezas de artillería, entre otros objetos, se relaciona en particular con la empresa I7 del libro de Saavedra, cuyo lema Alienis Spoliis (Los trofeos de otros) muestra una armadura y otros despojos bélicos sobre un tronco, pues "El árbol cargado de trofeos no queda menos tronco que antes. Los que a otros fueron gloria, a él son peso. Así las hazañas de los antepasados son confusión y infamia al sucesor que no las imita. En ellas no hereda la gloria, sino una acción de alcanzalla con la emulación”. Adelante, el preceptista ańade que las glorias de sus antepasados, como las que se figuraban en el primer carro de la mascarada al representar a Carlos V, “a él [el príncipe y en este caso al nuevo Carlos] son obligación de la nobleza, porque presuponemos que emularán los nietos las acciones de sus agüelos" ${ }^{63}$ En el carácter propiciatorio y optimista de todo el festejo se sobreentiende que Carlos II logrará, e incluso superará, las glorias de su tatarabuelo, por lo que el Marte en su trono simbolizará al dios cristianizado cediendo sus glorias al monarca. La advertencia de la empresa exalta las virtudes del "invicto sagrado joven", como llaman adelante al monarca, a punto de tomar las armas, pues ya se ha figurado como el dios bélico.

Quizá el emblema que tuvo más posibilidades de interpretación en esta máquina fue el que se formó con el águila a los pies del dios. Su epigrama, traducido, decía: "Entre la griega nación, de Júpiter soy llamada ave amiga, pero ahora a Marte México me atribuyó", ${ }_{4}$ que sin duda se refería al emblema VIII de Juan de Solórzano Pereira, titulado Optimus, ut maximus (Ser óptimo ${ }^{65}$ para ser el máximo) (fig. 4). ${ }^{66}$ Las modificaciones que sustituyeron a Júpiter por Marte se realizaron para que el dios guerrero se expresara como óptimo o benefactor y así fuera la liberalidad el sustento de su poderío, virtud representada por Solórzano mediante el águila que sostenía a Júpiter. ${ }^{67}$ Así, se podían atribuir al nuevo Marte las cualidades del águila, ampliamente descritas por los emblemistas y preceptistas de la época.

63. Diego de Saavedra Fajardo, Empresas políticas, Francisco Javier Díez de Revenga (ed.), Barcelona, Planeta, I988, p. I I4.

64. En el texto aparece en latín: "Graecam inter gentem dicor Iovis ales amica / Sed nunc me Marti, Mexicus attribuit”. Ramírez de Vargas, op. cit., p. 245.

65. Optimus también puede traducirse como bueno, benefactor o el mejor.

66. Los emblemas del libro de Solórzano Pereira Emblemata centum, regio politica, publicado en Madrid en I653, fueron dibujados por Roberto Cordier.

67. El jesuita Andrés Mendo, en su Príncipe perfecto y ministros ajustados, de I 662, repitió este emblema, como número tres, y con glosa en español. 
4. Juan de Solórzano Pereira, emblema VIII: Optimus, ut maximus, en Emblemata centum, regio politica, Madrid, Domingo García Moras, I653. Tomado de Cuadriello, "Los jeroglíficos de la Nueva España”, op. cit. (vid. infra n. 72), p. Ioo.

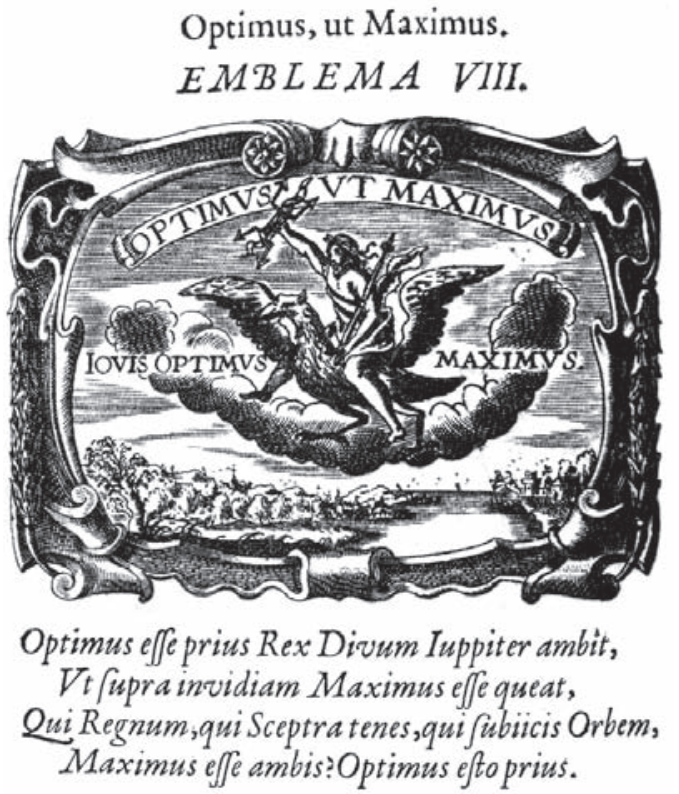

Ya que la relación entre Marte y la Pintura expresada en el carro novohispano era un tanto gratuita, quizá la inclusión del emblema Optimus, ut maximus para realizar un paralelismo entre Júpiter y Marte pudiera extenderse a otro del mismo libro donde se identifica a Júpiter como pintor, aunque el jurista tachó el retoque que Júpiter da a las mariposas como una actividad trivial. Se trata del emblema XXX, Magnus in magnis (El grande, en las cosas grandes), donde se ve a Jove sobre las nubes, paleta y pincel en mano, decorando las alas de una mariposa. ${ }^{68}$

Saavedra Fajardo, por su parte, también habla del águila con relación a Júpiter en su empresa 22, Praesidia maiestatis (Defensas de la majestad): "Si bien el consentimiento del pueblo dio a los príncipes la potestad de la justicia, la reciben inmediatamente de Dios, como vicarios suyos de lo temporal. Águilas son reales, ministros de Júpiter, que administran sus rayos, y tienen sus veces para castigar los excesos y ejercitar justicia”. Adelante, Saavedra señala las calidades del águila en los gobernantes: "la agudeza de la vista, para inquirir

68. También este emblema lo reprodujo Mendo, como el número I 5 de su libro. 
los delitos; la ligereza de sus alas, para la ejecución; y la fortaleza de sus garras, para no aflojar en ella". ${ }^{69}$ Además, el águila del carro, por supuesto, denotaba las armas del reino de la Nueva Espańa, mismas que Marte y por lo tanto después Carlos II habían de gobernar. Con ello también se adelantaba la imagen del aparato siguiente, en que América se rendía ante el Rey.

Pero aún otro simbolismo del águila fue aprovechado. Al llegar el carro a donde estaba el virrey, el joven que "hacía a Marte" recitó un romance explicativo del conjunto, pidiéndole descifrar la imagen que los pintores exhibían ante todos: una alegoría de la Pintura coronando al bélico dios. En su último verso, Marte se dirigía al prelado de la siguiente manera: "Éste es el carro, perdona / de Agustino águila noble, / que a quien no se dan tus plumas / despiden tus atenciones" $7^{0}$

Así, los implicados pedían a fray Payo, sacerdote agustino, tan sabio y agudo como de noble linaje, ${ }^{7 \mathrm{I}}$ que les regalase sus atenciones. Entonces el águila remitía a un emblema también fácilmente identificable que la destacaba de otros animales por considerársele el único ser capaz de ver al sol de frente y poner a prueba a sus polluelos en esta tarea. Los que no lo lograban eran desbarrancados por sus madres: eran "despedidos" de sus "atenciones". Así figuraron este emblema, entre otros, Hernando de Soto ${ }^{72}$ y Sebastián de Covarrubias. ${ }^{73}$ Qui-

69. Saavedra, op. cit., p. I 50.

70. Ramírez de Vargas, op. cit., p. 249.

7I. El Diccionario de autoridades de I 726 señala que águila es: "Ave bien conocida y Reina de todas las otras", y que una persona como águila "se da a entender la ligereza, velocidad, prontitud, viveza y perspicacia de alguna persona”. http://www.rae.es/ (consultado el 6 de enero de 2004), p. I30. El libro de Arfe y Villafañe también dedica unas líneas al águila, de las cuales reproduzco unos versos: "Entre las aves tiene el principado / el águila que es valiente y liberal / por que de cualquier cosa que ha cazado / parte con buena gana a cada cual". Arfe, op. cit., p. 79.

72. En su emblema A ti mesmo, de ti mesmo, cuyo epigrama decía: "Al sol que apunta al salir / Saca el Águila sus hijos, / A ver si con ojos fixos / Puede su luz resistir. / Luego al que ha resistido, / Por hijo suyo conoce, / Mas al otro desconoce, Y le arroja de su nido”. El libro de Soto se publicó en I 599. Tomé la transcripción del emblema de Jaime Cuadriello, "Los jeroglíficos de la Nueva España”, en Juegos de ingenio y agudeza. La pintura emblemática de la Nueva España, México, Museo Nacional de Arte, 1994, p. 96.

73. Sebastián de Covarrubias incluyó el tema en su emblema 79, Tu mihi solus eris: "Muchos autores graves han escrito, / El águila provar sus polluelos, / Si miran cara el sol, de hito en hito, / Y si no, los derrueca por los suelos. / O verdadero Sol, Dios infinito, / Si de mi pensamiento los hijuelos, / En vos no ponen toda su esperanza, / Deséchelos mi alma, sin tardanza”. El texto de Covarrubias citado es de I61 o. Ibidem, p. 96. 


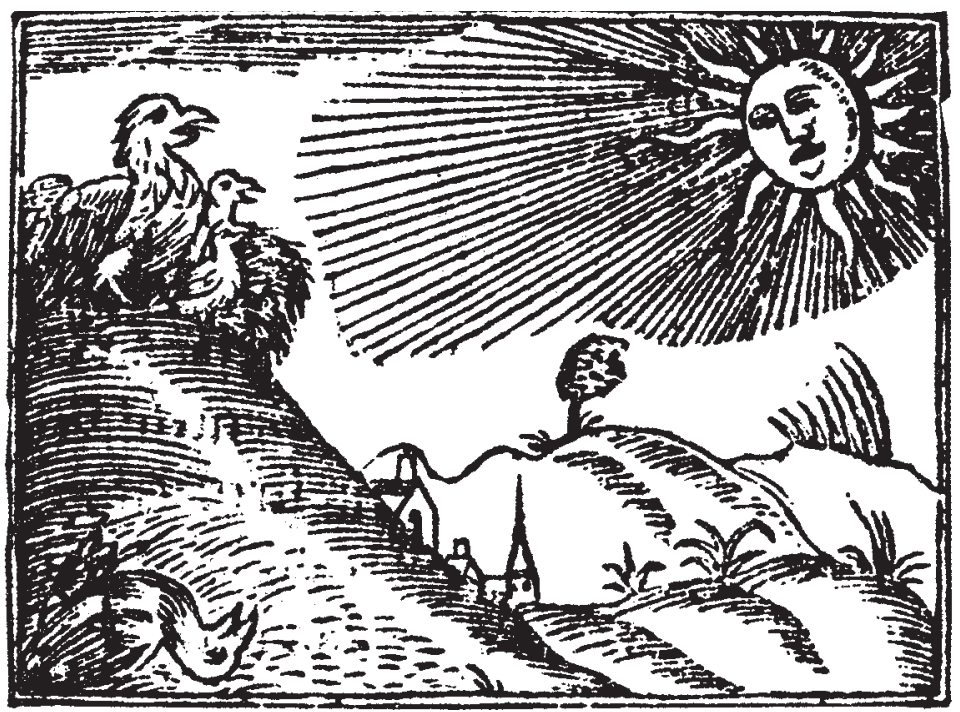

5. Hernando de Soto, emblema: A ti mesmo, de ti mesmo, en Emblemas moralizadas, Madrid, Herederos de Juan Íñiguez y Lequerica, I599. Tomado de Cuadriello, "Los jeroglíficos de la Nueva España”, op. cit. (vid. supra n. 72), p. 96.

zá con ello los pintores afirmaban que podían solicitar digna y directamente el favor del arzobispo-virrey (figs. 5 y 6 ).

Pero la figura del carro que lo singularizaba era la Pintura, personificación del arte como matrona con atributos identificables, quizá como la que describió Ripa con gran detalle al lado de otros conceptos como la Poesía y el Arte:

Mujer hermosa, con el cabello suelto, largo y negro, ensortijado de muy diversas formas y maneras, y cejas enarcadas, mostrándose con ello sus fantásticos pensamientos y meditaciones. Se ha de cubrir la boca con una banda que va atada por detrás de sus orejas, llevando al cuello una gran cadena de oro de la que cuelga una máscara, y leyéndose en medio de su frente: Imitatio. Ha de llevar el pincel en una de sus manos, sujetando un cuadro con la otra, apareciendo vestida con túnica de paño de variados colores que hasta los pies le cubre, y poniéndose luego junto a ellos algunos instrumentos de los que le son propios, para mostrar asi que la pintura es muy noble ejercicio, no pudiendo realizarse sin la dedicación del intelecto. ${ }^{74}$

74. Ripa, op. cit., t. II, p. 2 Io. Las cursivas son mías. 


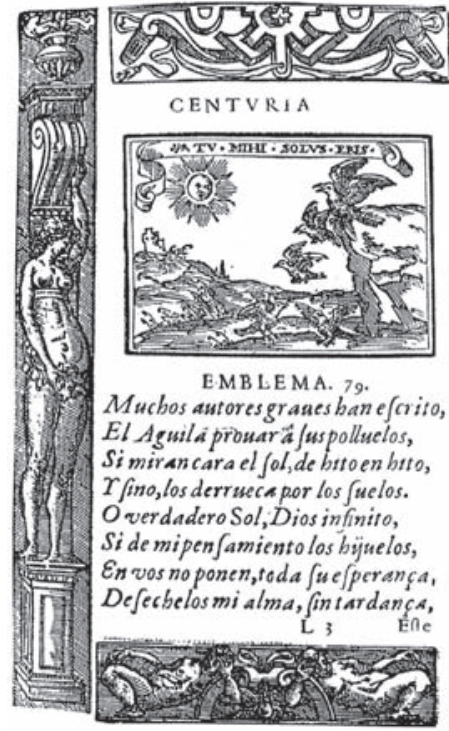

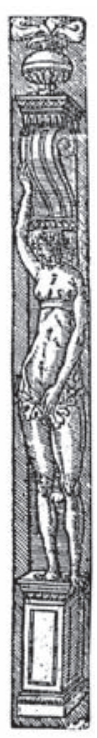

6. Sebastián de Covarrubias, emblema 79: Tv mihi solvs eris. Emblemas morales, Madrid, Luis Sánchez, I6ro. Tomado de Cuadriello, "Los jeroglíficos de la Nueva España" (vid. supran. 72), s.p.

Probablemente Carducho se inspiró en el texto de Ripa para realizar los grabados de su tratado que personificaron a la pintura, ${ }^{75}$ siendo quizá el primer pintor en España que la representó como una matrona.

Por ello, además del libro de Ripa, el tratado de Carducho pudo haber inspirado a los pintores novohispanos que la representaron como una hermosa

75. De la Pintura Ripa señaló también: "La boca amordazada, tal como ya dijimos, nos muestra que no hay cosa de tanto provecho para la actividad del pintor cuanto el silencio y la soledad, por cuya razón los que pintan tienen por costumbre encerrarse en lugares ocultos y secretos; pues no obran de este modo en razón a que teman la crítica y reprensión de las gentes a causa de la imperfección de su trabajo, según se suele decir y sostener vulgarmente. Ha de llevar además una cadena de oro donde cuelga una Máscara, para mostrar que el arte de la imitación está inseparablemente unido a toda la actividad de la pintura. En cuanto a los anillos que forman su cadena, muestran la conformidad y continuidad de una cosa con la otra, pues dice Cicerón en su Retórica que aunque el Pintor no toma todo de su Maestro, con una sola cosa todas a un tiempo aprende, pues le vienen unas con otras encadenadas en atención a su mutua similitud y conformidad. Será además de oro la cadena que digo, por las cualidades que muestra y simboliza este preciado metal, pues cuando en la pintura no alienta la nobleza, fácilmente se pierde y extravía, mostrándose con la Máscara de un modo general la imitación conveniente a dicho Arte". Ibidem, p. 2 I I. 
7. Grabado de Francisco López, en el tratado de Carducho, op. cit. (vid. supra fig. 2), acompaña el poema de Félix Lope de Vega y Carpio, tomado de George Kubler, "Vicente Carducho's allegories of painting", The Art Bulletin, vol. 47, 1965, p. 447.

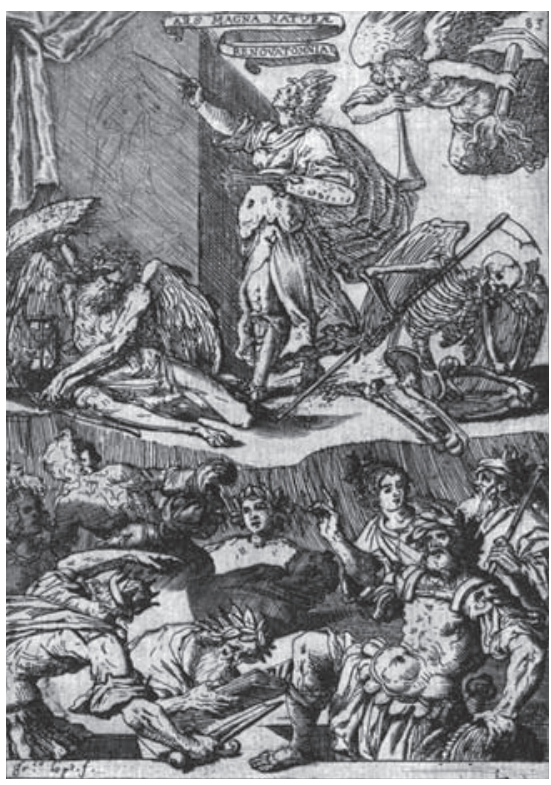

mujer coronando a Marte. Resaltan en particular dos estampas del tratado; la primera cierra el quinto diálogo y representa a la Pintura como soberana por su esencia intelectual y su poder de renovar la gloria y el tiempo (fig. 7). Félix Lope de Vega y Carpio culmina el correspondiente poema resaltando que, además de intelectual y bella, la pintura supera la verdad:

A ti que en perspectiva

Acercas lo más lejos

Entre confusas nieblas y reflejos,

Dulce mentira viva,

Engaño que deleita de tal suerte,

Que por menos hermoso

Deja lo natural quien llega a verte.

A ti que con descuido artificioso

Produjiste más árboles y flores

Que estudiosa de esmaltes y colores

La Aurora en la más fértil Primavera,

Frutos debe a la tierra más óptimos 
Ceres y Baco espigas y racimos, Cristal el agua, y risa lisonjeras, Canas los montes, y los valles faldas.

Los campos la cultura de esmeraldas, La mar sus ondas de argenteada espuma, Guedejas el León, la Fénix pluma, Imágenes los Signos y Planetas, El aire, nubes, rayos, y cometas, Y sus efigies Césares y Reyes.

Tú exenta, en fin, de las comunes leyes,

Divina en todo, por divino modo,

Si no lo crías, lo renuevas todo. ${ }^{76}$

El hecho de que la Pintura esté asociada con las victorias de los césares y los reyes era la única pero capital justificación que debieron tener los pintores novohispanos para incluirla en el carro de Marte. En ese sentido, el poema y el grabado de Carducho se relacionan con el concepto de la pintura como la memoria y la renovadora del pasado, un argumento utilizado por casi todos los tratadistas defensores de la liberalidad del arte desde Alberti. En el poema que recitó el Marte novohispano, mucho menos bello, se alude a la manera en que la pintura inmortalizaba las hazañas de los héroes:

Aquí, Señor, la pintura, como quien, en firmes bronces

los altos timbres imprime

de los ínclitos héroes,

vanamente me corona,

de los que adúltero nombre, me prohijó; bien que hoy a Carlos

por dueño suyo conoce. ${ }^{77}$

El poeta se refería así a la manera en que la pintura inmortalizaba las hazañas de los héroes, como lo hacía en el carro al coronar al Marte, aunque fuera va-

76. Carducho, op. cit., p. 256.

77. Ramírez de Vargas, op. cit., p. 248. 
namente, por ser los triunfos del Marte pagano. Adelanta que, por ello, el dios bélico ha reconocido a Carlos por su dueño, como lo hará la pintura:

\author{
Esas batallas y ese \\ de triunfos grave desorden, \\ en no caber en el lienzo, \\ bien que son suyos exponen \\ solos dirán mudamente \\ las victorias de Mavorte, \\ si quiere prestar la Fama \\ el aire a tantos pendones. ${ }^{78}$
}

Así, la pintura muestra las batallas y los triunfos de Carlos, tantos que no caben en los lienzos. Y se compara en estos versos a los pendones con las representaciones bélicas, que mudamente hablarán, como lo hace la pintura, si la fama presta su voz, como la poesía.

Pero en el carro novohispano también pueden reconocerse ciertas características mencionadas en el grabado octavo de Carducho, que cierra las ideas expuestas hasta entonces en el texto y refiere en forma directa al Memorial informativo $^{79}$ con el cual se concluye el tratado, al representar a la Pintura sobre las "otras" artes liberales: la escultura y la arquitectura (fig. 8). El lema Liberalium lux artiu[m] excelsa, o "Luz excelsa de las artes liberales", sintetiza perfectamente el contenido del pictograma. El poema que lo acompaña, de Juan Pérez de Montalbán, semeja un epigrama crecido, del que ofrezco unos fragmentos:

\footnotetext{
En superior lugar estoy sentada,

Ninguna puede competirme en nada;

Mi mano un Libro ofrece;

Una antorcha en la otra resplandece;
}

78. Idem.

79. El Memorial informativo es un texto que Carducho incluyó en su tratado; sin embargo, a petición del propio artista, había sido redactado por "siete sabios" para defender a los pintores cortesanos del pago de impuestos. El Memorial se publicó originalmente en I 629 con algunas diferencias respecto a la versión que apareció en el tratado. 


\section{IOO}

PAULA MUES ORTS

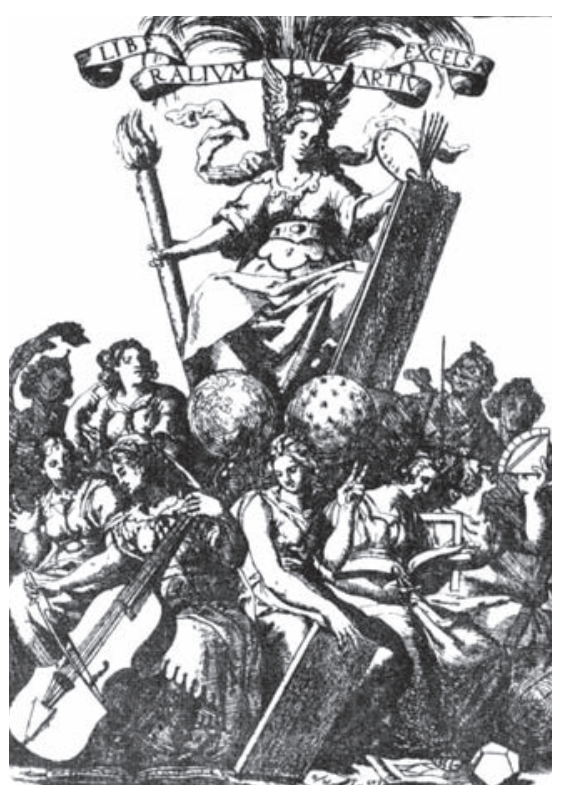

8. Grabado de Francisco López, en el tratado de Carducho, op. cit. (vid. supra fig. 2), que culmina el poema de Juan Pérez de Montalbán. Tomado de George Kubler, "Vicente Carducho's allegories of painting", The Art Bulletin, vol. 47, 1965, p. 378.

Dos palmas me coronan,

Y a mi lado dos Globos se eslabonan.

Éstas las partes son de mi hermosura,

Y ésta de mi Pintura la Pintura,

Si alguno lo dudare,

La causa escuche, y en mi voz repare,

Verá, que en gracia y modo

Todo lo soy, pues lo pruebo todo...

...La luz preclara dice,

Que de las otras artes doy felice.

Pues émula de todas en mi estado

Hablo, discurro, intimo, persuado,

Mido, canto, y del Cielo

Los astros averiguo vuelo a vuelo, 
Sin que haya ciencia humana,

Que mi deidad no incluya soberana...

Dios fue mi Autor en mi primera infancia,

Dando a Moisés el modo, y la distancia,

El dibujo, o Tabernáculo de Cielo:

Porque Dios solamente

Pudo dar luz a luz tan excelente. ${ }^{80}$

La personificación novohispana resulta similar, pues tras el trono de Marte:

Paraba una figura de talla ricamente vestida de siete colores que a no significar la pintura la hubieran tenido por la ninfa Iris o la consorte de Titón [...] En cuyos siete colores mostraba servirse de las siete artes liberales, llevando en la mano derecha un laurel con que iba coronando a Marte; en la izquierda, la paleta y pinceles que la denotaban; un compás, una regla y un cuadrante, con cuya sinécdoque explicaba la Geometría y las demás artes subalternadas en ella. ${ }^{8 \mathrm{I}}$

Personificar a las otras artes, como en el grabado de Carducho, hubiera producido confusión, incluso más de la que debió causar a algunos espectadores ver a la Pintura en este carro.

Puede decirse que los pintores que crearon el aparato utilizaron tanto las ideas e imágenes de Cesare Ripa como aquéllas expresadas en los grabados emblemizados de Carducho, pero también, como se vio antes, recurrieron a temas y representaciones de los tratados de emblemas políticos o conceptos comunes en el lenguaje emblemático, lo cual indica que, como grupo, los artífices novohispanos podían valerse de herramientas de su propia disciplina así como de otras que seguramente tomaban prestadas. Me parece importante reiterar que el grupo de pintores también supo reconocer en el virrey a un escucha espectador capaz de entender sus mensajes visuales y sonoros, y que seguramente el agustino no los "despidió" como a "polluelos" incapaces de ver el sol.

Falta, para culminar con la idea del carro y pasar al epílogo, preguntarse quiénes pudieron ser los pintores que aprovecharon la oportunidad para hacer la declaración acerca de la utilidad y calidad de su arte. Varios son los artífi-

8o. Carducho, op. cit., pp. 450-45 I.

8 I. Ramírez de Vargas, op. cit., p. 247. 
ces que estaban activos en I676 en la ciudad de México y conforman un grupo interesante y prolífico que enlazaba a los nacidos en las décadas de I630 y I640. El más prominente seguramente era Baltasar de Echave Rioja (I632I682), quien culminaba una dinastía brillante que desde su inicio dio muestras de orgullo pictórico, como sucedió cuando Baltasar de Echave Orio, abuelo de Echave Rioja, se autorretrató como escritor y pintor en un mismo grabado.

Juan Sánchez Salmerón (ca. I635-I697) quizá fue otro de los artistas presentes en la formulación alegórica, pues ya se le había reconocido como uno de los facultativos importantes cuando participó en la inspección del ayate de la Virgen de Guadalupe en I666. Probablemente este artista realizó la primera enunciación pictórica novohispana para proponer que el ayate guadalupano había sido pintado en el taller celestial, eligiendo al Espíritu Santo como su ejecutante material, asistido por Cristo, Dios Padre y varios ángeles. ${ }^{82}$ Este lienzo toluqueño sin duda se apoyaba en la aceptación del milagro de la imprimación del ayate, pero también en la teoría pictórica que hacía a Dios el primer practicante del arte.

Antonio Rodríguez (I636-I69I) y Pedro Ramírez (I638-I679) también debieron participar en la creación del carro. El primero fue heredero de un taller familiar de gran importancia para la Nueva Espańa. El reconocimiento que alcanzó puede imaginarse por la referencia a él que hizo fray Matías de Escobar en su Thebaida americana, obra publicada en I729, donde lo llamó "el Tiziano de este nuevo mundo". ${ }^{83}$ Por su parte, antes de las fiestas a Carlos II, Pedro Ramírez probablemente había trabajado en otras celebraciones importantes, pues se piensa que fue el constructor de la montea del túmulo funerario de Felipe IV en la Catedral de México en I666. ${ }^{84}$

Juan Correa (ca. I646-I7I6), Cristóbal de Villalpando (ca. I646-I7I4), José Rodríguez Carnero (ca. I650-I725) e Hipólito de Rioja (¿-I702) eran maestros más jóvenes que seguramente participaron también en las fiestas en honor al monarca. Todos ellos incrementaron su producción alrededor de I680, con-

82. Debo citar el estudio de Jaime Cuadriello respecto a este cuadro, pues en él analiza con profundidad el ambiente intelectual que seguramente le dio origen: "El obrador trinitario o María de Guadalupe creada en idea, imagen y materia”, en Cuadriello (ed.), El divino pintor..., op. cit., pp. I49-I 53.

83. La referencia se cita en Manuel Toussaint, Pintura colonial en México, México, Universidad Nacional Autónoma de México-Instituto de Investigaciones Estéticas, I990, p. I I 2.

84. Aunque lo duda, Toussaint planteó que el pintor debió ser el autor nombrado en el texto de Isidro de Sariñana que describe las ceremonias fúnebres. Ibidem, p. Io7; Cuadriello, "Los jeroglíficos...", op. cit., p. 9I. 
solidando hacia entonces sus talleres y estilos más personales, por lo cual podría pensarse que fueron los beneficiarios del trabajo conjunto de los artistas mencionados antes.

\section{Epílogo: a la vista devota o reservada, o de la calle al altar o a la casa}

Poco después de la solicitud de atención que los pintores hicieron públicamente a Enríquez de Ribera en 1676, comenzaron a experimentarse cambios en el grupo de artífices, también visibles a todos: bajo el gobierno del sucesor de fray Payo, el marqués de la Laguna, los pintores iniciaron los trámites para la reconstitución formal de su gremio. El I de agosto de I68I, José Rodríguez Carnero y Antonio Rodríguez solicitaron al ayuntamiento de México una copia de las ordenanzas de 1557 para estudiarlas y proponer unas nuevas que los beneficiaran. Esta restructuración finalizó en 1687 cuando se pregonaron las nuevas ordenanzas.

Probablemente hacia 1676 se logró una cohesión, ratificada más tarde con la reorganización institucional y legal que les otorgaba el gremio. No debe olvidarse que para participar en las fiestas en honor al monarca el corregidor llamó a los "gremios", entre los cuales contó a los pintores aunque no estuvieran en esos momentos legalizados por el ayuntamiento. En I687, con la institución gremial nuevamente formalizada, se abrió la puerta para el liderazgo artístico y corporativo de una nueva generación, encabezada por figuras como Villalpando y Correa y, por tanto, beneficiarios directos de la iniciativa de 1676 .

Los años siguientes a 1676 fueron sin duda de fortalecimiento para los pintores. Grandes instituciones, como los cabildos catedralicios de México, Puebla y Guadalajara, patrocinaron obras importantes y, junto con el mecenazgo de muchos colegios y conventos, contribuyeron para que los artífices de finales del siglo Xvir pudieran calificarse de prolíficos. En los muchos encargos que tuvieron pintores como Villalpando y Correa, éstos aprovecharon ocasionalmente los espacios religiosos para hacer pequeñas declaraciones pictóricas a favor de su arte, como por ejemplo el posible autorretrato que Villalpando dejó en la sacristía metropolitana, el cual sería muestra de su orgullo facultativo, o la que mostró Juan Correa al reentelar, para la iglesia Profesa, un lienzo de la Virgen de las Nieves, en el cual agregó al santo pintor, vanidad e insignia de su arte, como se jactaban las disquisiciones teóricas de los tratados que enaltecían a la pintura por medio de san Lucas. 
En el ámbito secular seguramente los pintores tuvieron más libertades para exponer las ideas acerca de su trabajo, pero por desgracia no han quedado obras que puedan considerarse concluyentes respecto a las intenciones o concepciones artísticas de los pintores de esta época. Una de las piezas que tal vez pudiera dar pistas al respecto, tradicionalmente ligada al patrocinio de fray Payo Enríquez de Ribera, está, también por desgracia, incompleta. Se trata del biombo pintado por Juan Correa que por un lado ostenta dos de los cuatro Elementos $y$, por el otro, cinco de las siete Artes liberales.

El mueble, hoy en el Museo Franz Mayer, lo compró el coleccionista a un descendiente de la casa del duque de Medinaceli, pariente del marqués de la Laguna y por supuesto del arzobispo-virrey fray Payo. ${ }^{85} \mathrm{El}$ patrocinio de este último parece muy probable debido a que, como se ha visto, su padre Fernando Afán fue un ávido comprador de arte. El complejo diseño y la temática erudita del biombo, que también parecen coincidir con la personalidad de quien fue arzobispo-virrey, cobran una perspectiva diferente si se les relaciona con el poderoso gobernante y con el ambiente artístico de la época de su mayor esplendor: aquellos años en que los pintores exhibieron ante sus ojos la personificación de su arte.

El biombo utiliza el lenguaje emblemático al combinar imágenes y versos en el lado de los Elementos. Las seis hojas que conforman el biombo incompleto reproducen de este lado los carros del Aire y la Tierra (fig. 9). Los libros moralizados de Ovidio son una de las fuentes más utilizadas para estas representaciones, como ya lo ha expuesto Marita Martínez del Río de Redo en varias ocasiones. ${ }^{86}$ Los Elementos y demás dioses mitológicos aparecen en carros triunfales, con sus atributos y los de las estaciones del año marcadas por los signos zodiacales en las ruedas y centros de los mismos. Evidentemente, en las hojas faltantes estarían los carros del Agua al centro y del Fuego al extremo opuesto. Quizá en medio pudiera haber sido representado el tiempo, como Cronos o Saturno, refiriéndose al paso de las estaciones que caracterizan a los Elementos. ${ }^{87}$

85. Marita Martínez del Río de Redo seńala que Jaime de Medina, nieto de "los marqueses de Tarifa", era el dueño del biombo incompleto. "Dos biombos...”, op. cit., p. 467.

86. Además del artículo de la autora ya mencionado, debe citarse su trabajo "Los biombos en el ámbito doméstico: sus programas moralizadores y didácticos”, en Juegos de ingenio y agudeza..., $o p$. cit. Cesare Ripa incluyó el carro de los elementos y las estaciones como tema de representación, pero el biombo no parece estar tomado de este autor en cuanto a sus formas puntuales.

87. La ubicación de los elementos faltantes puede deducirse de las estaciones del año marcadas por los signos zodiacales de los carros. Saturno aparece pintado en el Invierno de una serie quiteña 
El lado de las Artes liberales es más significativo para el tema tratado, pues en un contexto en que los pintores defendieron que su arte era una de ellas, parecería lógico aludir a su facultad en su representación. Las Artes liberales, representadas como matronas en emblemas triplex, son, de izquierda a derecha: la Gramática, la Astronomía, la Retórica, la Geometría y la Aritmética (fig. Io). La sexta hoja del biombo muestra a cuatro de las nueve musas señalando hacia el extremo donde una cartela anuncia la presencia de Minerva, "madre de todas las artes". Faltan necesariamente, para completar el mensaje, cinco musas más, así como la Música y la Lógica. Llama la atención de inmediato que las Artes no están ordenadas según la clasificación tradicional del Trivium y Quadrivium, pues el primero se formaba por las artes teóricas: Retórica, Lógica y Gramática, mientras que el segundo comprendía las artes poéticas y prácticas: Aritmética, Geometría, Música y Astronomía. ${ }^{88}$

Muchas pudieron haber sido las fuentes conceptuales del biombo, así como al parecer fueron abundantes y variadas las formales, pero más importante que la precisión de alguna principal o única que hasta el momento se ha resistido a ser identificada sería tratar de completar el mensaje de la obra, para lo cual es necesario relacionar el biombo con su entorno. Salta a la vista que las figuraciones mitológicas comunes en las fiestas - como las celebradas en I676, en que aparecieron dioses mitológicos y musas- pudieran ser una posible referencia a este tipo de representaciones.

En este biombo parecen entrelazarse varios hilos: la sensibilidad erudita y educada del arzobispo-virrey (quien al parecer no rehuyó ciertos placeres de la vida secular de palacio), su herencia paterna como gran patrocinador artístico, las aspiraciones artísticas y sociales de los pintores expresadas en su carro y la cultura emblemática y alegórica, llena de recursos simbólicos. Juntos forman

de las estaciones, del pincel de Miguel de Santiago. Nancy Morán de Guerra y Alfonso Ortiz de Crespo señalan, en el comentario de la obra para Los siglos de oro en los virreinatos de América I550-I700, op. cit., pp. 332-334, que la serie debió realizarse alrededor de I670 y está inspirada en Ripa y Pacheco.

88. Hay ciertas diferencias entre los autores al citar las artes liberales, pues mientras algunos señalan la dialéctica en vez de la retórica, otros manejan dialéctica y lógica como sinónimos. $C f r$. Raymond Bayer, Historia de la estética, México, Fondo de Cultura Económica, I998, pp. 95-96; Moshe Barasch, Teorías del arte. De Platón a Winckelmann, Madrid, Alianza (Alianza Forma, I08), I99I, p. 48; Wladyslaw Tatarkiewicz, Historia de seis ideas. Arte, belleza, forma, creatividad, mímesis, experiencia estética, Madrid, Tecnos (Metrópolis), 1992. 


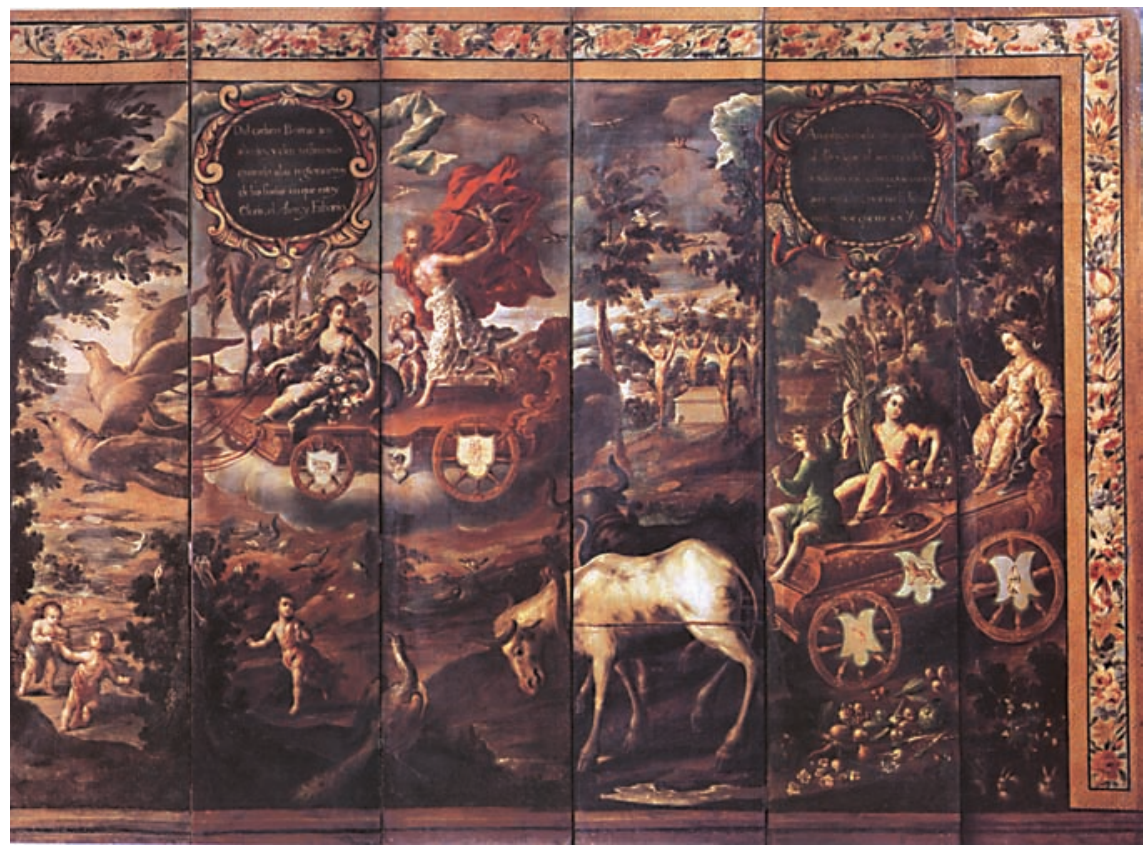

9. Juan Correa, biombo, Las artes liberales y los cuatro elementos (reverso: Los cuatro elementos), ca. I670, 6 hojas (incompleto), óleo sobre lienzo, $242 \times 324 \mathrm{~cm}$, Museo Franz Mayer. Tomado de Elías Trabulse, Arte y ciencia en la historia de México, México, Fomento Cultural Banamex, I995, p. 77.

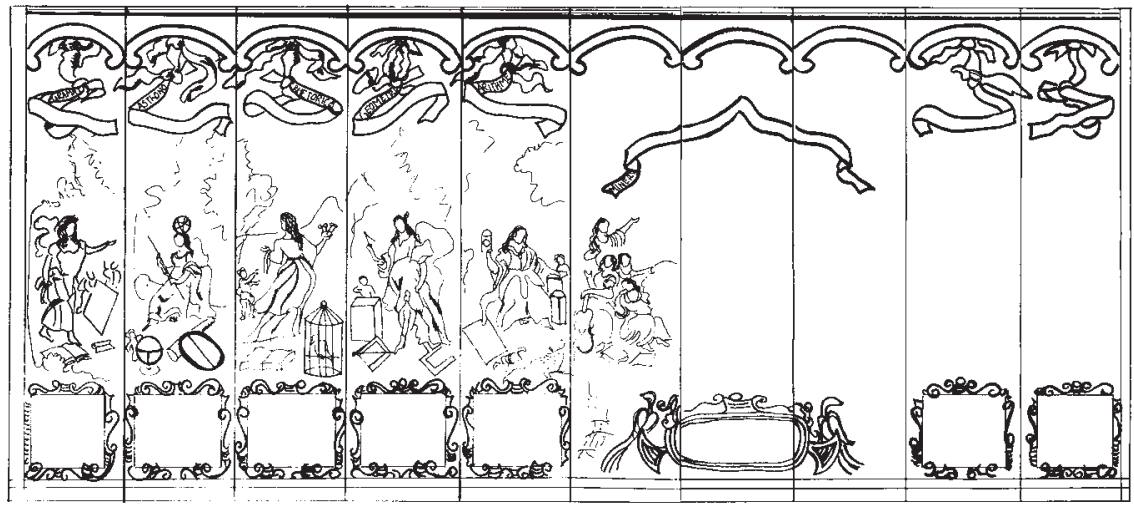

I I. Reconstrucción de Artes con ro hojas, anverso del biombo de Las artes liberales y los cuatro elementos, pintado por Juan Correa. Dibujo: Paula Mues Orts. De izquierda a derecha: Gramática, Astronomía, Retórica, Geometría, Aritmética, Musas, Minerva, Musas, Música y Lógica. 


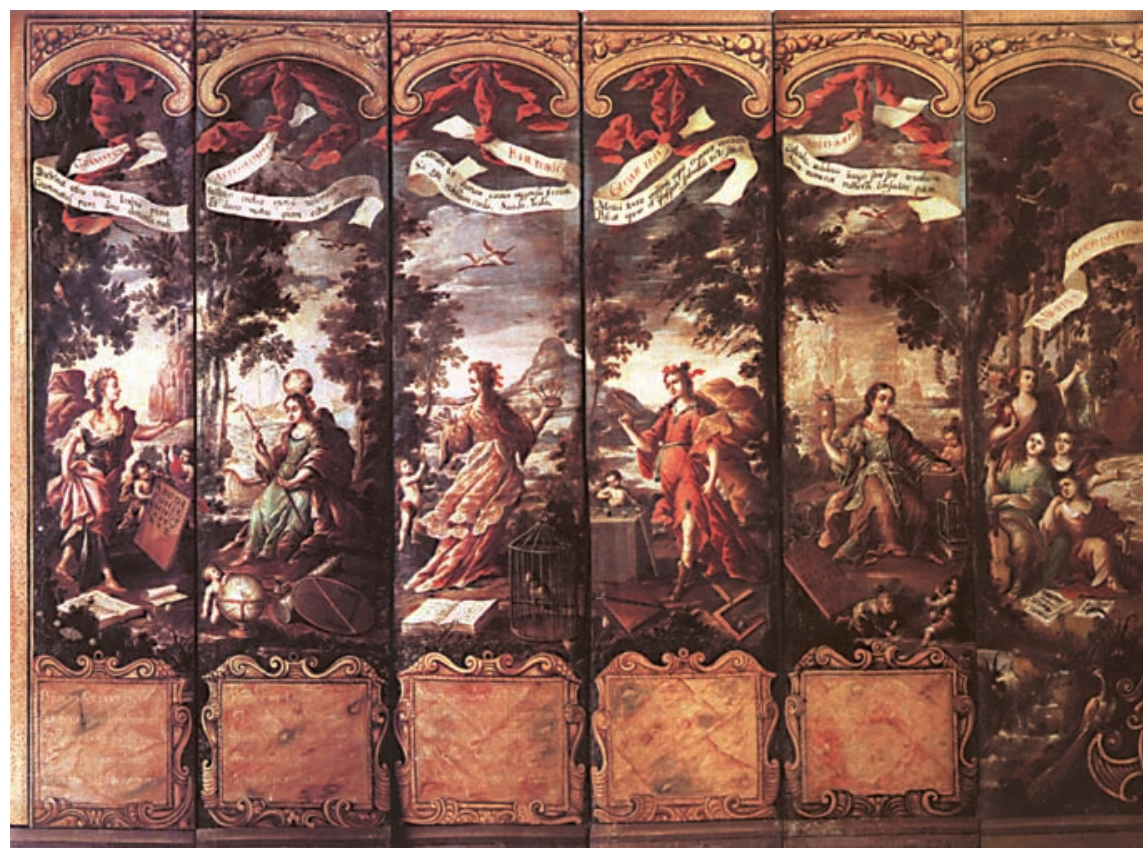

Io. Juan Correa, biombo, Las artes liberales y los cuatro elementos (anverso: Artes), ca. I670, 6 hojas (incompleto), óleo sobre lienzo, $242 \times 324 \mathrm{~cm}$, Museo Franz Mayer. Tomado de Elías Trabulse, Arte y ciencia en la historia de México, México, Fomento Cultural Banamex, 1995, p. 76.

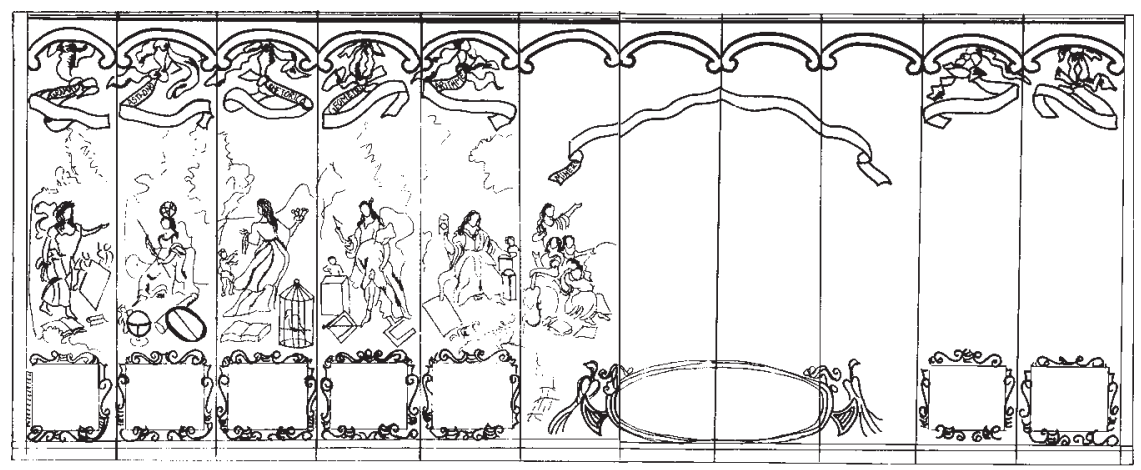

I2. Reconstrucción de Artes con I I hojas, anverso del biombo de Las artes liberales y los cuatro elementos, pintado por Juan Correa. Dibujo: Paula Mues Orts. De izquierda a derecha: Gramática, Astronomía, Retórica, Geometría, Aritmética, Musas, Minerva, Apolo, Musas, Música y Lógica. 


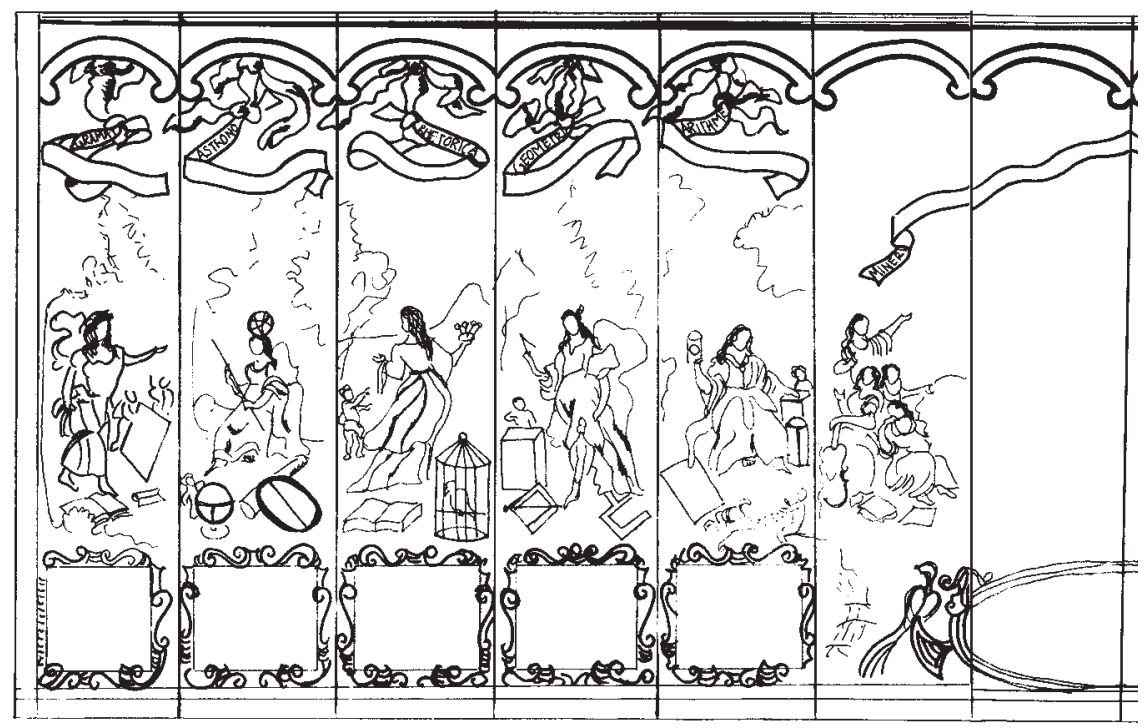

I3. Reconstrucción de Artes con I4 hojas, anverso del biombo de Las artes liberales y los cuatro elementos, pintado por Juan Correa. Dibujo: Paula Mues Orts. De izquierda a derecha: Gramática, Astronomía, Retórica, Geometría, Aritmética, Musas, Minerva, Apolo, Musas, Lógica, Música, Pintura, Escultura, Arquitectura.

una trama que da pie a imaginar la posible solución del problema que plantea el biombo incompleto de Juan Correa.

En un juego de imaginación deseo "completar" el programa del biombo utilizando esos recursos simbólicos de manera plástica, como quizá hubiera hecho el pintor. La primera posibilidad consiste en delinear una hoja para Minerva, otra para las musas faltantes y dos más, para la Música y la Lógica (fig. II). Así se tendrían las siete artes liberales canónicas, pero no una composición demasiado afortunada. Puede agregarse una hoja más, intentando perfeccionar coherentemente el mensaje del biombo: bien pudiera habitarla el dios solar Apolo, protector de las artes; así se completaría la iconografía del monte Parnaso, con sus dos cumbres y la fuente Hipocrena, que brota detrás de las musas en la hoja sobreviviente (fig. I2). Descrito por los humanistas como una figuración terrena de las esferas celestiales, en la Roma renacentista el monte Parnaso se convirtió en una atractiva metáfora de la recuperación de la armonía primitiva de las artes y las ciencias en torno al patrocinio y la protección 


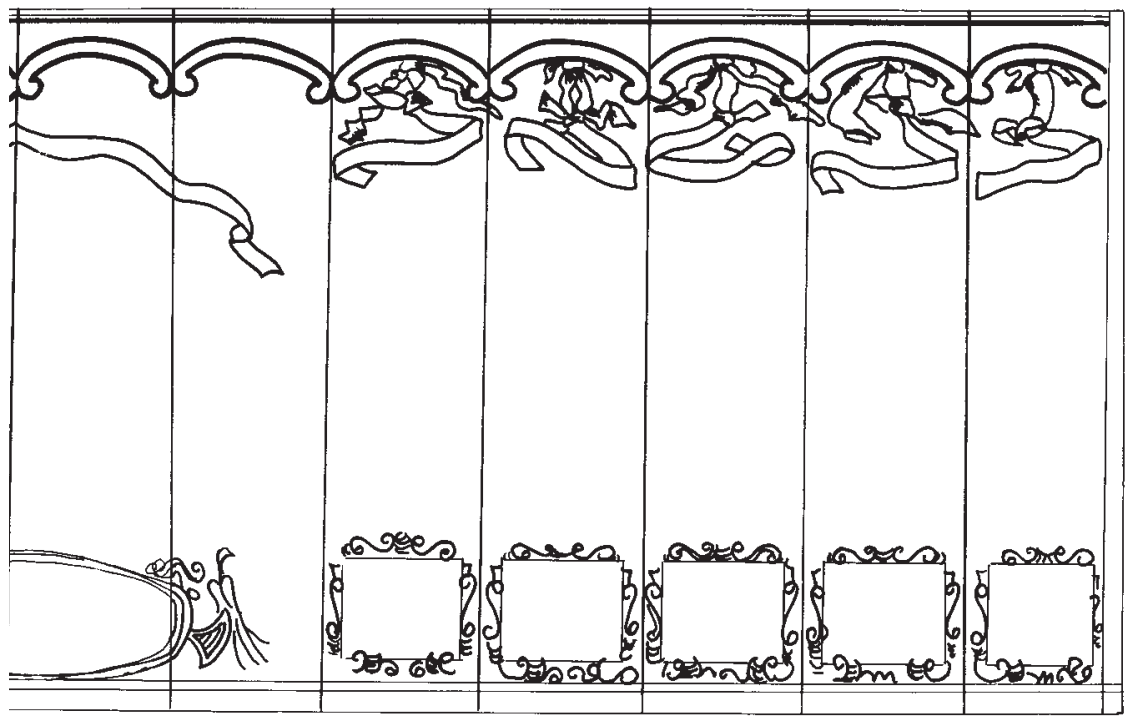

del sumo pontífice o de cualquier otro príncipe poderoso y sabio. A su vez, los emblemistas, como Otto Vaenius en su Emblemmata horatiana de I607, hicieron de la reunión de Minerva, Apolo y las musas en el Parnaso la alegoría de las artes como reposo del espíritu en los trabajos de la virtud. Finalmente, el movimiento academicista italiano, desde Vasari hasta los Carracci y Federico Zuccaro, hizo de la inclusión de los pintores entre los poetas y músicos bienaventurados que habitan el monte sagrado el símbolo de la cualidad eminentemente intelectual del arte pictórico. ${ }^{89}$

Esta solución, sin embargo, aún dista mucho de ser formalmente perfecta. En cambio, al agregarse tres hojas a esta última posibilidad, se alcanza un balance compositivo acorde con la refinada sensibilidad artística de tan grande patrono. Tres hojas que, siendo consecuentes con la forma de pensar del mecenas y de estos artistas, tendrían que haber mostrado a otras tres artes que reclamaban su nobleza: la Pintura, la Escultura y la Arquitectura (fig. I3). Quizá algún día sepamos si éste ha sido sólo un juego especulativo, como los que la

89. Todo lo anterior según Marc Fumaroli, "L'Inspiration du poète de Poussin: les deux Parnasses", en Roger Jacot, L'École du silence. Le sentiment des images au XVIIe siécle, París, Flammarion, I998, pp. 52-I 47, especialmente las pp. 63-72 y 86-94. Agradezco a Jaime Cuadriello por haberme proporcionado este texto fascinante. 
cultura emblemática tanto apreciaba, o si efectivamente esas artes dieron forma a las hojas faltantes del biombo.

De cualquier manera, los pintores, conscientes de que la teoría que comparaba la poesía con la pintura era uno de los mejores argumentos para la defensa de su arte, siguieron usando este recurso de manera constante en obras profanas, en las que su utilidad se relacionaba con la preceptiva política. Así, los pintores novohispanos se enorgullecieron, en mi opinión, de la importancia de sus creaciones y de la liberalidad simbolizada por el lienzo en blanco, como señalaban Diego de Saavedra Fajardo —en su empresa segunda- y Vicente Carducho, quien culminó su propio tratado recordándonos la importancia del ingenio en la pintura, con el emblema Potentia ad actum tamquam tabula rasa (La potencia es al acto como la tabla rasa), en que un pincel se dispone a delinear la primera idea:

En la tabla rasa tanto excede, que ve todas las cosas en potencia, sólo el pincel con soberana ciencia, reducir la potencia al acto puede. $\$$

N.B. La primera versión de este ensayo se presentó originalmente como ponencia en el V Seminario Internacional de Emblemática Filippo Picinelli, el 30 de enero de 2004, en la ciudad de México. Escribirlo fue posible gracias a un espíritu de apoyo semejante al que debieron experimentar los pintores novohispanos en la empresa que aquí narro. Agradezco infinitamente a Jaime Cuadriello por su auxilio, sus libros, recomendaciones e insistencia; a Rosario Granados por acordarse de mis temas y recomendarme textos; a Antonio Rubial por facilitarme referencias de consulta fundamentales; a Gabriela Sánchez Reyes por confiarme su trabajo; a Elda Pasquel por su apoyo constante; a Daniela Cruz por ayudarme a completar el cuadro; a Verónica Zaragoza por compartir conmigo sus conocimientos y leer mis bosquejos; a Jaime Aldaraca y Kiara Spallanzani por la poesía; y a Iván Escamilla por todo, pero especialmente por sus trazos.

* Artículo recibido el I7 de mayo de 20 I I; aprobado el 26 de septiembre de 20 I I. 